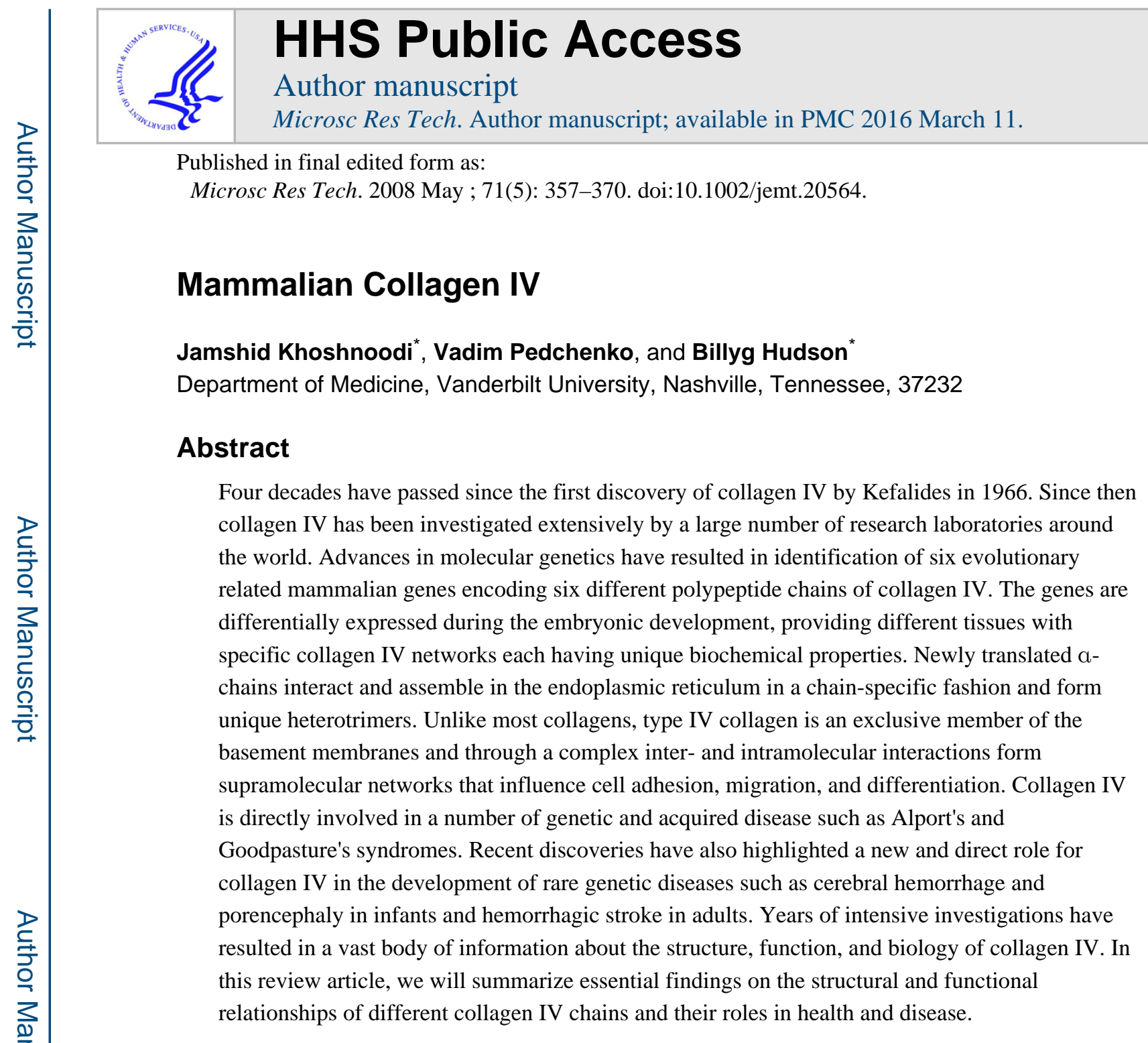

Keywords

collagen IV; basement membrane; Alport's syndrome; Goodpasture's syndrome

\title{
Introduction
}

Type IV collagen is a unique member of the large collagen superfamily which in vertebrates comprise 28 different types (Myllyharju and Kivirikko, 2004; Veit et al., 2006). Unlike most collagens, type IV collagen occurs only in the basement membranes (BMs) and comprises up to six genetically distinct a-chains designated a1(IV) to a6(IV). Out of many potential combinations, the chains interact and assemble with a remarkable specificity to form only three distinct heterotrimers of a1a1a2, a3a4a5, and a $5 a 5 a 6$. The a1(IV) and a2(IV) chains, which were first to be described and thus called "classical" chains, are present in the

\footnotetext{
*Correspondence to: Jamshid Khoshnoodi, Division of Cardiovascular Medicine, Vanderbilt University School of Medicine, 383 Preston Research Building, 2220 Pierce Avenue, Nashville, Tennessee 37232-6300, USA. jamshid.khoshnoodi@ vanderbilt.edu or Billy G. Hudson, Division of Nephrology and Hypertension, Department of Medicine Vanderbilt University School of Medicine S-3223 Medical Center North 1161 Twenty-first Avenue South Nashville, Tennessee 37232-2372, USA. billy.hudson@vanderbilt.edu.
} 
$\mathrm{BM}$ of all tissues, whereas the other four chains have restricted tissue distribution during the development. For example, the a3(IV), a4(IV), and a5(IV) chains are present in the glomerular basement membrane (GBM) of the kidney, lung, testis, and eye, whereas the a5(IV) and a6(IV) chains are found in the BM of skin, smooth muscle, and the kidney. The expression of collagen IV chains is also subjected to temporal regulation. For instance, in the GBM of human kidney, genes encoding the a1(IV) and a2(IV) chains are expressed during early embryonic development (day 75), but their levels gradually decrease as the expression of genes encoding the a3(IV), a4(IV), and a5(IV) chains starts. This developmental switch in gene expression is absolutely critical for the maturation of the GBM as a specialized plasma filtration barrier in the kidney. While most identified mutations in the genes encoding either a1(IV) or a2(IV) are embryonic lethal, most mutations in genes encoding the a3(IV), a4(IV), or a5(IV) chains leads to renal failure and deafness in adult patients with Alport's syndrome (Hudson, 2004; Hudson et al., 2003).

\section{Gene Organization and Regulation}

Human collagen IV genes are arranged in three pairs with head-to-head orientation; COLAA1-COLAA2 on chromosome 13, COL4A3-COL4A4 on chromosome 2, and on chromosome X (Fig. 1). Sequence analyses from several mammalian species have pointed to a common ancestral gene, which through three consecutive gene duplications has resulted into six evolutionary related genes (Zhou et al., 1994). Based on sequence similarity, the genes can be divided into a1-like group including COLAA1, COLAA3, and COL4A5 genes, and a2-like group comprising COLAA2, COLAA4, and COLAA6 genes. The members of each group also share conserved sequence features such as characteristic exon-intron organization, indicating their evolutionary relationships. The bidirectional promoters shared by the paired genes is another unique feature of collagen IV, which is not shared by other collagen families. For example on the chromosome 13, COLAA1 and COLAA2 genes are transcribed from opposite DNA strands with transcription starting sites separated only by $\sim 130$ bp (Heikkila and Soininen, 1996). Similarly, the genes encoding a5(IV) and a6(IV) chains on chromosome $\mathrm{X}$ also share their promoter, however, the a6(IV) chain was shown to be encoded by two transcripts differing in their $5^{\prime}$-end sequences encoding different signal peptide (Oohashi et al., 1994; Sugimoto et al., 1994; Zhou et al., 1993). With no evidence for alternative splicing, these two transcripts were suggested to be regulated by two promoters (Sugimoto et al., 1994). Unlike other paired collagen IV genes, differential expression of COLAA5 and COLAA6 genes has been reported, indicating that transcription through alternative promoters may be used to differentiate COL4A6 gene expression from that of COLAA5 (Sugimoto et al., 1994).

Despite extensive studies and identification of the regulatory elements in the promoter regions, the regulation of collagen IV genes are not well understood. For example, the mRNA levels for a1(IV) and a2(IV) chains varies in different cells and under different conditions, yet the ratio of translated a-chains in the triple-helical a 1a 1 a 2 molecule remains always the same. This indicate that the expression of collagen IV genes are highly regulated on different levels such as transcription, stability and processing of encoding RNAs, efficiency of translation and posttranslational modifications, and last but not least, the chainspecific recognition of different a-chains in the cell. Alternative splicing is another 
contributing factor to the complexity of chain composition and assembly of collagen IV achains. Analyses of a3(IV) chain in human kidney samples have revealed the presence of alternatively spliced transcripts, while no alternative spliced variants have been detected for the a1(IV), a2(IV), a4(IV), or a6(IV) chains (Bernal et al., 1993; Feng et al., 1994).

\section{Structural Properties and Supramolecular Organization}

In mammals, the collagen IV family comprises six highly homologous, yet genetically distinct a-chains (Fig. 1 and Table 1). Each chain contains three structurally distinct domains; an amino-terminal domain rich in cysteine and lysine residues, a major collagenous Gly-Xaa-Yaa triple repeats of $\sim 1,400$ residues, followed by a $\sim 230$-residue long carboxy-terminal noncollagenous (NC1) domain (Hudson et al., 2003). The presence of cysteine- and lysine-rich residues at the amino terminus is essential for interchain crosslinking of four triple-helical molecules through disulfide bonds and lysinehydroxylysine crosslinks. The crosslinked tetramer is heavily glycosylated making it resistant to collagenase activity. Following bacterial collagenase treatment of the BMs, the crosslinked tetramer can be isolated as a large molecular complex with a sedimentation coefficient of 7S, thus called the 7S domain (Risteli et al., 1980; Timpl et al., 1979). Another characteristic feature of collagen IV is the presence of 21-26 interruptions in the collagenous Gly-Xaa-Yaa triple repeats. The interruptions in the collagenous domain not only provide molecular flexibility for network formation but some of them also serve as cell-binding sites and interchain crosslinking (Vandenberg et al., 1991). The number of interruptions varies between chains, being the lowest in the a 1 chain with 21 interruptions and the highest in a4 chain with 26 interruptions (Table 1).

The carboxy-terminal $\mathrm{NC} 1$ domain is also resistant to bacterial collagenase treatment and is easily isolated from collagenase treated BMs. The $\mathrm{NC} 1$ domains are the sites for molecular recognition through which the stoichiometry of chains in the assembly of triple-helical formation is directed (Khoshnoodi et al., 2006a). Study of the NC1 interactions have provided insights into chain-specific assembly of collagen IV chains, and therefore have been the focus of extensive study for the past three decades. Following treatment with bacterial collagenase, the $\mathrm{NC} 1$ domains can be purified from the BMs and studied as a hexamer. Recently, solution to crystal structure of the $\left[(\mathrm{a} 1)_{2} \mathrm{a} 2\right]_{2} \mathrm{NC} 1$ hexamer has provided detailed structural information about the complex intermolecular interactions of the NC1 domains (Sundaramoorthy et al., 2002; Than et al., 2002). It was shown that each NC1 hexamer consists of two identical heterotrimers with a molecular stoichiometry of two a1 and one a $2 \mathrm{NC1}$ domains. Both heterotrimers form a flat surface through which they interact end-to-end forming a compact ellipsoid-shaped molecule (Fig. 2). Since there are 12 conserved cysteine residues in each $\mathrm{NC} 1$ domain, it has long been thought that interchain disulfide bonds occur between different $\mathrm{NC} 1$ domains. However, it was revealed that the hexamer is stabilized through extensive hydrophobic and hydrophilic interactions without involvement of any di-sulfide bond. Furthermore, it was shown that the NC1 domains within each trimer interact through a three-dimensional domain swapping mechanism. In this type of interaction, the domain swapping motif (a $\beta$-hairpin structure) from each $\mathrm{NC} 1$ domain is "swapped" into a docking site (a four-stranded antiparallel $\beta$-sheet) located on the neighboring $\mathrm{NC} 1$ domain. Within each trimer, every $\mathrm{NC} 1$ domain "donates" a domain 
swapping $\beta$-hairpin motif to one neighboring $\mathrm{NC} 1$ domain and accept a similar motif from another NC1 domain (Fig. 2). Such high degree of intermolecular complexity provides a high degree of specificity for chain selection through $\mathrm{NC} 1$ trimers, which function as a "folding origin" for triple-helical assembly of the entire collagen molecule. Thus the carboxy-terminal $\mathrm{NC} 1$ domains can be considered as the initial directors for the molecular assembly of the collagen IV molecules (Khoshnoodi et al., 2006a).

Once secreted into the extracellular matrix (ECM), the triple-helical molecules self-associate to form distinct networks providing a molecular scaffold onto which other ECM components such as laminins, perlecans, and proteoglycans can interact. The supramolecular structure of collagen IV network in situ was studied by Yurchenco and Ruben (1987) using highresolution electron microscopy. Detailed analyses of high-resolution electron micrographs revealed that collagen molecules assemble to form irregular polygonal networks held together predominantly by overlapping lateral interactions along the triple-helical domain as well as the N-terminal and C-terminal end-domains (Fig. 2). More importantly, they showed that supercoil formation by supramolecular twisting is a characteristic feature of lateral associations which provides further stability to the network (Yurchenco and Ruben, 1987). Thus, through complex intermolecular interactions, these highly specialized ECM components form a remarkable set of tissue-specific BMs involved in many biological processes such as cell adhesion, migration and development, tissue regeneration and wound healing, reservoir of growth factors and enzymes, and in molecular sieving.

\section{Biosynthesis and Modifications}

Similar to other collagens, the biosynthesis of collagen IV is a complex process involving many co- and posttranslational modifications catalyzed by several specific and nonspecific enzymes (Myllyharju and Kivirikko, 2004). These enzymatic modifications are highly coordinated and include removal of the signal peptide in the endoplasmic reticulum (ER), hydroxylation of many proline and lysine residues, glycosylation of specific hydroxylysine residues, addition of mannose-rich oligosaccharide, and finally the formation of important intrachain disulfide bonds between the 12 conservative cysteine residues in the $\mathrm{NC} 1$ domain. In addition, biosynthesis of collagens is highly dependent on at least one specific molecular chaperon, Hsp47, without which proper folding will not take place (Matsuoka et al., 2004; Nagai et al., 2000).

In collagen IV, $N$-linked oligosaccharides are exclusively located in the $7 \mathrm{~S}$ domain, whereas hydroxylysine-linked disaccharides are scattered along the entire molecule. The evolutionary conservation of $\mathrm{N}$-linked glycosylation sites on the $7 \mathrm{~S}$ domain in all chains and across different species strongly suggests that this posttranslational modification plays important role in the alignment and assembly of collagen IV network in the BMs (Langeveld et al., 1991; Nayak and Spiro, 1991). After alignments, the 7S domains are cross-linked through interchain disulfide bonds and perhaps also through covalent lysyl-hydroxylysine bonds, which introduce further stability to the collagen network.

Covalent crosslinks have also been reported for the $\mathrm{C}$-terminal $\mathrm{NC} 1$ domains in the collagen IV networks. It has long been known that isolated $\mathrm{NC1}$ hexamers can dissociate into 
monomers and dimers by acid or other denaturant treatments. The presence of both reducible and nonreducible NC1 dimers have been repeatedly reported in different tissues such as kidney, placenta, aorta, and mouse Engelbreth-Holm-Swarm tumor (Boutaud et al., 2000; Langeveld et al., 1988; Siebold et al., 1988; Weber et al., 1984). Such dimers have long been assumed to be disulfide crosslinked monomers formed through a reshuffling mechanism of disulfide bonds during network formation (Netzer et al., 1998b; Siebold et al., 1988). However, the relative amount of nonreducible dimers isolated from different tissues varies significantly, for example 70\% in BM of placenta but only 30\% in BM of lens capsule (Langeveld et al., 1988; Vanacore et al., 2004).

The true nature of the crosslinked $\mathrm{NC} 1$ dimers and their tissue-dependent variation in relative amount has been puzzling for over two decades. Recent determination of X-ray crystal structure of $\mathrm{NC} 1$ hexamer reported from two independent laboratories have clearly disproved the interchain disulfide crosslink hypothesis (Sundaramoorthy et al., 2002; Than et al., 2002). Based on electron density maps at 1.9-A resolution, however, a novel thioether crosslink between a methionine residue on one chain and a lysine residue on the opposite chain was proposed (Than et al., 2002). The chemical nature of this unusual covalent bond was further investigated by others. Based on trypsin digestion of separated monomer and dimer fractions, a crosslinked peptide unique to the dimer fraction was isolated and shown to derive from two a $1 \mathrm{NC} 1$ domains (Vanacore et al., 2005). Mass spectrometry and chemical analysis of the crosslinked peptide suggested that the crosslink occurred between the side chain of a methionine residue on one chain and a hydroxylysine on the other. The novel crosslink was named $S$-hydroxylysyl-methionine and suggested to be synthesized through two posttranslational modifications; hydroxylation of the lysine residue to hydroxylysine and formation of the covalent bonds between the hydroxylysine and sulfur atom of the methionine side chain. Disregard of the chemical nature and biosynthesis of this unusual crosslink, the presence of such unique covalent modification is most likely to be catalyzed by specific enzyme(s) present in a tissue-specific manner. Isolation and characterization of such posttranslation modifying enzyme(s) will be another intriguing research area in the biosynthesis of collagens.

\section{Discovery of Chains and the Question of Assembly}

A common feature among collagens of all types is that, they consist of three polypeptide chains (a-chains) with repeating Gly-X-Y sequences which have high propensity to form supercoiled triple-helical structure (Brodsky and Ramshaw, 1997; Brodsky and Shah, 1995; Jenkins and Raines, 2002). Some collagens, such as collagen III, are obligate homotrimers comprising three identical a-chains, whereas others form heterotrimers containing at least two different a-chains (Prockop and Kivirikko, 1995). As ubiquitous as they are, many types of collagens are expressed in the same cell, yet in the ER they are all assembled in a type- and chain-specific manner with correct stoichiometry before they are secreted into the ECM.

Similar to many collagens, the assembly of collagen IV starts from the carboxy-terminal ends, where specific interactions between $\mathrm{NC} 1$ domains direct the stoichiometry of chains in a triple-helical molecule. While assembly of other heterotrimeric collagen types involves 
recognition between two or three different a-chains, assembly of the collagen IV molecules includes selection among six different a-chains. Theoretically, these six a-chains could assemble into 76 different combinations including six homotrimers and 70 heterotrimers. However, only three specific heterotrimers (a1a1a2, a3a4a5, and a5a5a6) have so far been found in all tissues studied (Borza et al., 2001; Boutaud et al., 2000; Hudson et al., 1994, 2003). This finding reflects a remarkable specificity among the a-chains of collagen IV, and raises a fundamental question about the underlying mechanism in the chain selection and formation of different heterotrimers. The extraordinary ability for chain selection makes the collagen IV the "prototype" molecule to delineate the mechanism of chain selection in the assembly of collagens. In addition, the detailed structural information which was recently obtained through solution of its NC1 crystal structure makes collagen IV an ideal molecule to decipher the structural basis of the sites involved in chain recognition and selection. The assembly question has been subjected for intensive investigation through the years. Here we describe some of the highlights.

\section{Evolution of Assembly Question}

In 1981, the first network model for the organization of collagen IV was reported (Timpl et al., 1981). Using rotary shadowing technique, it was demonstrated that individual collagen IV molecules appeared as 390-nm long strands with a globular domain which was termed noncollagenous domain ( $\mathrm{NC1}$ ). Two of such molecules could form a dimer through interaction of their $\mathrm{NC} 1$ domain. In protein fractions that had been solubilized by pepsin digestion, the $\mathrm{NC} 1$ domains disappeared and the remaining molecules mainly consisted of four triple-helical strands joined together through the amino terminal $7 \mathrm{~S}$ domains. Thus it was demonstrated that collagenous network of BMs consists of collagen IV molecules with two different interacting sites; a 7S domain which connects four molecules and the NC1 domain which connects two molecules. Soon after, it was shown that the NC1 domain consisted of $\sim 30,000$ molecular weight polypeptide located at the carboxyl end of the molecule and contained intramolecular disulfide bridges (Fessler and Fessler, 1982).

Until mid 80s, only two a-chains of collagen IV were known to exist. However, based on chemical analysis of the GBM, the existence of minor but different collagen IV subunits was known for several years. Following digestion of the GBM with bacterial collagenase and chemical analysis of isolated NC1 domains, evidence for the existence of two novel achains, named a3(IV) and a4(IV), with different amino acid sequences than those derived from the classical a1(IV) and a2(IV) chains were reported (Butkowski et al., 1985, 1987; Wieslander et al., 1985). Based on partial peptide sequences derived from isolated NC1 domains of human GBM (Butkowski et al., 1990; Gunwar et al., 1990; Kleppel et al., 1986; Saus et al., 1988), partial cDNA clones were soon isolated by PCR amplification (Mariyama et al., 1992; Morrison et al., 1991a,b). Shortly, this was followed by characterization of the complete primary structure of the human a3(IV) and a4(IV) chains and their genes were localized to human chromosome 2 (Leinonen et al., 1994; Mariyama et al., 1994; Quinones et al., 1992; Turner et al., 1992). With the discovery of a5(IV) and a6(IV) chains by molecular cloning, the fundamental question of chain-specificity was revived. The ability of collagen IV chains to self-assemble through interactions at their NC1 domains had already been reported in early 80s (Timpl et al., 1981). Pepsin-treated molecules which lacked their 
NC1 domains were also shown to lack the ability to form network (Yurchenco and Furthmayr, 1984). Using rotary shadowing technique, a time-dependent reassembly of heatdenatured collagen IV molecules was clearly visualized, demonstrating a zipper-like refolding fashion of the triple-helical molecule starting from the C-terminal NC1 domains and proceeding toward the N-terminal ends (Dolz et al., 1988). Direct evidence that the chain specificity of collagen assembly is encoded by the NC1 domains was first demonstrated using purified $\mathrm{NC} 1$ hexamers isolated from BMs of different tissues (Boutaud et al., 2000). It was shown that acid-dissociated NC1 hexamers had the ability to reassemble back to native configuration with the original molecular stoichiometry. More interestingly, it was shown that hexamer formation from the $a 3, a 4$, and $a 5 \mathrm{NC} 1$ monomers required the presence of all three $\mathrm{NC} 1$ domains, further suggesting that mutations in individual $\mathrm{NC} 1$ domains may interrupt the assembly of the a $3 a 4 a 5$ network. All these findings clearly highlighted the critical role of the NC1 domain in the assembly of collagen IV molecules, and suggested that the $\mathrm{NC} 1$ domains contain recognition sequences for chain selection.

Using detailed kinetics and crystal structure analysis, we have recently reported the molecular mechanism of chain-selection in the assembly of collagen IV (Khoshnoodi et al., 2006b). Using a surface plasmon resonance biosensor, the kinetic of interaction and assembly of isolated a1(IV) and a2(IV) NC1 domains were determined. The analysis showed that the a2(IV) NC1 domain had a prominent role in regulating the stoichiometry of chains and assembly of a 1a1a2 hetero-trimer, by displaying a significantly higher affinity for heterodimer formation with a1(IV) NC1 domain than with itself. As the chain-specific assembly of the collagen IV molecules is initiated by the early interactions of NC1 domains in the ER, this characteristic differential affinity of certain $\mathrm{NC} 1$ domains for dimer formation may play a major regulatory role in determining the stoichiometry of chains in a particular collagen IV molecule. Moreover, based on data derived from the atomic structure of the $\mathrm{NC} 1$ hexamer, two prominent regions which together provide specificity for chain selection were identified. These regions comprised a 13-residue long $\beta$-hairpin motif involved in the domain-swapping mechanism stabilizing the intermolecular interaction between two $\mathrm{NC1}$ domains, and a 15-residue long region with genetic hypervariability (VR3) which mediates chain-specific recognition between two NC1 domains (Fig. 2) (Khoshnoodi et al., 2006b). Thus it is most likely that chain-specific assembly of triplehelical collagen IV molecules in the ER is governed mainly by two factors: (i) specific recognition sites located on each $\mathrm{NC} 1$ domain and (ii) differential affinity of particular achains for dimer formation. Based on sequence identity, both a4(IV) and a6(IV) chains belong to the a2-like subtype and also occur only once in a $3 a 4 a 5$ and a $a 5 a 6$ trimers, respectively. Therefore, it is likely that these chains also play a regulatory role in the assembly of their corresponding triple-helical molecules.

\section{Interaction To Cell Surface Receptors}

In addition to providing a scaffold for assembly and mechanical stability, collagen IV is an important component in interaction of cells with underlying basement membrane. This interaction is critical for a variety of biological processes, including cell adhesion, migration, survival, proliferation, and differentiation. Cell culture studies have shown that collagen IV is the binding substrate for a large number of cell types including platelets (Santoro, 1986; 
Staatz et al., 1990), hepatocytes (Rubin et al., 1981), keratinocytes (Murray et al., 1979), endothelial (Cheng and Kramer, 1989; Herbst et al., 1988), mesangial (Setty et al., 1998), pancreatic (Kaido et al., 2004), and tumor cells such as breast and prostate carcinoma (Abecassis et al., 1987; Dedhar et al., 1993), melanoma (Chelberg et al., 1989), fibrosarcoma, and glioma (Aumailley and Timpl, 1986; Knight et al., 2000). Cell attachment to collagen IV is mediated by multiple binding sites within both triple-helical and NC1 domains, suggesting involvement of several adhesion receptors (Chelberg et al., 1989; Herbst et al., 1988; Wayner and Carter, 1987). These receptors can be divided into integrin and nonintegrin receptors.

\section{Integrin Receptors}

Integrins comprise a large number of structurally and functionally related transmembrane glycoproteins which are the major cell surface receptors for the ECM (Hynes, 1987, 1992, 2002). On the cell surface, they are present as noncovalent heterodimers consisting of an aand a $\beta$-subunit. Each subunit has a large extracellular domain, a short transmembrane segment, and a C-terminal cytoplasmic tail with affinity for cytoskeletal proteins. Thus the term integrins reflect their ability to "integrate" cells into their immediate environment by connecting the cytoskeleton with the extracellular components. So far, $18 \mathrm{a}-$ and $8 \beta$-subunits have been identified in mammalian cells and are known to interact in a tissue-restricted manner to form 24 distinct family members (Humphries et al., 2006; Hynes, 2002). This diversity is further expanded by alternative splicing, posttranslational modifications, and interaction to other cell surface receptors and intracellular molecules (de Melker and Sonnenberg, 1999; Green et al., 1998; Porter and Hogg, 1998).

An important characteristic feature of integrins is their ability to recognize short peptide sequences within large ECM proteins. The classical example of integrin binding site is the Arg-Gly-Asp (RGD) sequence originally identified in fibronectin, which is a common ligand for at least eight different integrins (Ruoslahti, 1996). Although multiple RGD sequences exist within the triple-helical region of several collagen IV a-chains, several studies have shown that cell adhesion to collagen IV is RGD-independent (Herbst et al., 1988; Kim et al., 1994; Kramer and Marks, 1989). A possible explanation is that due to their triple-helical nature, these RGD sequences are not accessible to integrins. However, cell adhesion to collagen IV is predominantly dependent on triple-helical state of collagen IV, since reduction of disulfide bonds followed by heat-denaturation dramatically decreases cell binding and spreading (Aumailley and Timpl, 1986; Perris et al., 1993; Santoro, 1986).

The major collagen receptor include the $\beta_{1}$ subgroup of integrins, namely $\alpha_{1} \beta_{1}$ and $\alpha_{2} \beta_{1}$ (Aumailley and Gayraud, 1998; Leitinger and Hohenester, 2007; Paulsson, 1992). These two integrins bind both collagen IV and collagen I, however, with distinct specificity as follows: integrin $\alpha_{1} \beta_{1}$ has a higher affinity for collagen IV, while $\alpha_{2} \beta_{1}$ binds stronger to collagen I (Kern et al., 1993; Tulla et al., 2001a). It was shown that deletion of $\alpha_{1} \beta_{1}$ integrin by the homologous recombination resulted in dramatic decrease in adhesion and migration of fibroblasts and smooth muscle cells to collagen IV substrate (Gardner et al., 1996), while the importance of $\alpha_{2} \beta_{1}$ integrin was demonstrated by the decrease of adhesion and morphogenesis on collagen IV after using antisense mRNA (Keely et al., 1995). A major 
binding site for $\alpha_{1} \beta_{1}$ and $\alpha_{2} \beta_{1}$ integrins has been originally identified within a triple-helical cyanogen bromide-derived fragment CB3, located $100 \mathrm{~nm}$ away from the amino-terminus of the collagen IV (Fig. 3) (Vandenberg et al., 1991). The triple-helical conformation of this particular region of the molecule is stabilized through interchain disulfide bridges between the a1(IV) and a2(IV) chains. Using antibodies to CB3 fragment, it was shown that about $80 \%$ of cell adhesion to collagen IV was inhibited, suggesting that it comprises a major cell binding region. By affinity chromatography using immobilized CB3 fragments and cellular lysates, $\alpha_{1} \beta_{1}$ and $\alpha_{2} \beta_{1}$ were isolated as the only integrins eluted from the affinity column (Vandenberg et al., 1991). Using purified integrins and shorter tryptic fragments of CB3, one binding site for $\alpha_{1} \beta_{1}$ integrin and two for $\alpha_{2} \beta_{1}$ integrin were located in different but adjacent positions on CB3 fragment (Kern et al., 1993). Further refinement of the $\alpha_{1} \beta_{1}$ recognition site was achieved by digestion of one of the tryptic peptides with thermolysin (Eble et al., 1993). Thus, the recognition site within CB3(IV) fragment was located within a conformational-dependent region, where the spatial vicinity of Asp461 on a1(IV) chain to Arg461 on a2(IV) chain showed to be critical for binding of $\alpha_{1} \beta_{1}$ integrin. Finally, functional activity of this site for $\alpha_{1} \beta_{1}$ integrin binding has been demonstrated directly using synthetic triple-helical peptide containing 12 amino acid residues (457-468) from both a1 and $a 2$ chains of collagen IV stabilized with artificial cysteine knot (Renner et al., 2004).

Similar to $\alpha_{1} \beta_{1}$, a conformational-dependent binding to collagen I and IV has been shown for $\alpha_{2} \beta_{1}$ integrin (Knight et al., 1998). The $\alpha_{2} \beta_{1}$ integrin plays an important role in platelet adhesion to collagens and hemostasis in the blood vessel wall (Sixma et al., 1997). It has been shown that a short sequence of GFOGER peptide ( $\mathrm{O}$ being hydroxyproline) represents a binding site for the $\alpha_{2} \beta_{1}$ integrin (Knight et al., 2000). The sequence represents a highaffinity binding site in both collagen I and IV, and is entirely dependent on the native triplehelical conformation. Replacement of phenylalanyl or glutamyl residues abolished the binding, indicating their important role for recognition. Triple-helical GFOGER peptide is a potent inhibitor of cell adhesion to collagen IV. Moreover, this sequence is present in a1 chain of CB3(IV) fragment (385-390), where it might represent one of the two binding sites for $\alpha_{2} \beta_{1}$ integrin (Fig. 3).

In addition to $\alpha_{1} \beta_{1}$ and $\alpha_{2} \beta_{1}$, other integrins may also participate in cell binding to collagen IV. Cell adhesion to collagen IV mediated by $\alpha_{3} \beta_{1}$ integrin was shown for small lung carcinoma cell line expressing low levels of other $\beta_{1}$ integrins (Elices et al., 1991). In addition, $\alpha_{3}$ subunit antisense oligonucleotide partially inhibited adhesion of prostate carcinoma cells to collagen IV (Leung-Hagesteijn et al., 1994). One binding site for $\alpha_{3} \beta_{1}$ integrin has been identified on a 1 chain of collagen IV (residues 531-543) using synthetic peptide GEFYFDLRLKGDK, which promoted adhesion of several tumor cell lines and induced $\alpha_{3} \beta_{1}$-mediated signal transduction (Lauer et al., 1998; Miles et al., 1994, 1995). However, the role of $\alpha_{3} \beta_{1}$ as a collagen IV receptor remains controversial since integrinspecific antibody failed to block the adhesion of various cells (Elices et al., 1991; Melchiori et al., 1995), and overexpression of $\alpha_{3} \beta_{1}$ does not increase adhesion to the collagen IV (Delwel et al., 1994; Weitzman et al., 1993). Most surprisingly, genetic ablation of $\alpha_{3}$ integrin increases adhesion and migration of keratinocytes on collagen IV leading to the hypothesis that $\alpha_{3} \beta_{1}$ is a trans-dominant inhibitor of collagen IV binding integrins (Hodivala-Dilke et al., 1998). Finally, the $\alpha_{3} \beta_{1}$ integrin complex, either as recombinant or 
purified from cells, has failed to bind collagen IV in vitro (Eble et al., 1998; Pochec et al., 2003).

Recently, binding of two new integrins, $\alpha_{10} \beta_{1}$ and $\alpha_{11} \beta_{1}$, to collagen IV have been reported (Tiger et al., 2001; Tulla et al., 2001b). The $\alpha_{11}$ I domain binds stronger to collagen I through the same GFOGER motif as $\alpha_{2} \beta_{1}$ integrin (Zhang et al., 2003), while binding of $\alpha_{10}$ is more specific for collagen IV similar to $a_{1}$ I domain (Tulla et al., 2001b). Nevertheless, structure of binding sites for these two integrins on collagen IV remains unknown.

Expression of $\alpha_{10} \beta_{1}$ and $\alpha_{11} \beta_{1}$ is spatially and temporally restricted to chondrocytes and fetal muscle cells, suggesting their specific role in development.

Thermal denaturation or proteolytic degradation results in exposure of novel binding sites on collagen molecules. This phenomenon was first described for collagen I, which after thermal denaturation binds fibronectin with increased affinity (Engvall and Ruoslahti, 1977; Schor and Court, 1979), and later for collagen IV (Aumailley and Timpl, 1986). These results led to suggestion that cell adhesion to denatured collagen could be mediated by fibronectin- $\alpha_{5} \beta_{1}$ integrin bridge (Tuckwell et al., 1994). More recent studies show the exposure of a cryptic site within the triple-helical part of the collagen IV after proteolytic cleavage (Xu et al., 2001). This cleavage occurred in blood vessels during angiogenesis and was associated with a loss of $\alpha_{1} \beta_{1}$ and concomitant gain of $\alpha_{\mathrm{v}} \beta_{3}$ integrin binding. Moreover, monoclonal antibodies to denatured collagen IV inhibited angiogenesis and tumor growth in vivo. These results suggest that degradation and proteolytic remodeling of BMs might expose cryptic sites within collagen IV with altered integrin specificity and biological functions.

In addition to the triple-helical part, $\mathrm{NC} 1$ domain of collagen IV also promotes cell adhesion (Chelberg et al., 1989; Herbst et al., 1988; Setty et al., 1998), stimulates outgrowth of embryonic neurons (Lein et al., 1991), and inhibits morphogenesis in Hydra vulgaris (Zhang et al., 1994). The latter finding led to the suggestion that NC1 domain could inhibit angiogenesis by disrupting the assembly of vascular basement membrane (Sarras and Hudson, 1997). Subsequent studies with purified recombinant NC1 domains demonstrated that $\mathrm{a} 2, \mathrm{a} 3$, and a $6 \mathrm{NC} 1$ domains promote the adhesion and migration of endothelial cells, while a1, a4, and a5 NC1 domains were inactive (Petitclerc et al., 2000). Interestingly, systemic administration of $\mathrm{a} 1, \mathrm{a} 2$, and $\mathrm{a} 3 \mathrm{NC} 1$ domains also inhibits tumor growth and angiogenesis in vivo (Colorado et al., 2000; Maeshima et al., 2000b; Petitclerc et al., 2000). Inhibition of cell adhesion with neutralizing antibodies suggests that different $\mathrm{NC} 1$ domains may bind distinct integrins: $\alpha_{1} \beta_{1}$ for $\alpha_{1} \mathrm{NC} 1, \alpha_{\mathrm{v}} \beta_{3}, \alpha_{\mathrm{v}} \beta_{5}$, and $\alpha_{3} \beta_{1}$ for $\mathrm{a}_{2} \mathrm{NC} 1$, and $\mathrm{a}_{\mathrm{v}} \beta_{3}$ for a 3 and a $6 \mathrm{NC} 1$ domains (Fig. 3). Somewhat different results were obtained for melanoma and ovarian carcinoma cells which interact with $\alpha_{2} \mathrm{NC} 1$ domain through $\alpha_{1} \beta_{1}$ and $\alpha_{v} \beta_{3}$ integrins (Roth et al., 2005). Recently, we directly identified $\alpha_{v} \beta_{3}$ and $\alpha_{v} \beta_{5}$ integrins as endothelial receptors for a $3 \mathrm{NC} 1$ domain by affinity chromatography and confirmed binding of purified integrins in vitro (Pedchenko et al., 2004). So far, specific integrin binding sites have been characterized only for a $3 \mathrm{NC1}$ domain (Han et al., 1997; Maeshima et al., 2000a). One region was initially identified within the first half of a3 NC1 domain (residues 54-132), since corresponding recombinant protein inhibited proliferation of endothelial cells, induced apoptosis, and decreased tumor growth in nude mice (Maeshima et al., 2001a).

Subsequently, shorter synthetic peptide derived from this region (residues 74-98) was 
shown to inhibit proliferation of endothelial cells presumably via interaction with $\alpha_{v} \beta_{3}$ integrin in a RGD-independent manner (Maeshima et al., 2001b). This results in inhibition of the Cap-dependent protein synthesis mediated by focal adhesion/ phosphatidylinositol-3/Akt/mTOR kinases (Maeshima et al., 2002; Sudhakar et al., 2003). A second cell-binding site was ascribed to amino acids 185-203 of a $3 \mathrm{NC1}$ domain based on the inhibition of melanoma cells proliferation by the corresponding synthetic peptide (Han et al., 1997). This peptide binds $\alpha_{v} \beta_{3}$ integrin and CD47/IAP from the cell lysate through specific interaction of $\beta_{3}$ subunit with amino acid triplet SNS (Pasco et al., 2000; Shahan et al., 1999). In addition, we recently found that endothelial cell adhesion to recombinant a3 $\mathrm{NC} 1$ is critically dependent on the interaction of the adjacent amino terminal RGD motif with $\alpha_{v} \beta_{3}$ integrin as deletion of RGD sequence significantly decreased cell adhesion, and the two above-mentioned peptides were unable to recapitulate cell adhesion to a $3 \mathrm{NC} 1$ domain (Pedchenko et al., 2004). Thus, NC1 domains of collagen IV act as ligands for distinct integrins through several binding sites that may mediate their anti-angiogenic and anti-tumor activities.

Interaction of cells with 7S domain of collagen IV has been reported by several groups, suggesting the existence of an additional yet uncharacterized binding site for cell adhesion receptors. Purified 7S domain efficiently blocks cell aggregate development in Hydra, suggesting that it may play an important role in morphogenesis (Zhang et al., 1994). In another report, the $7 \mathrm{~S}$ domain potently stimulated chemotaxis in neutrophils, and this response is potentially mediated by a $67-\mathrm{kD}$ lectin-like protein similar to the elastin receptor (Senior et al., 1989).

\section{Nonintegrin Receptors}

Evidence has also been reported for cell-collagen IV interaction through nonintegrin receptors, such as cell-surface heparin sulfate proteoglycans, glycoprotein VI and mannose receptor family (Leitinger and Hohenester, 2007). Melanoma cells expressing the chondroitin sulfate proteoglycan CD44 bind directly to collagen IV, and cell interaction and migration could be inhibited by anti-CD44 antibodies (Knutson et al., 1996). Using synthetic triple-helical peptides, the binding site for CD44 has been localized to a 14-residue long region within the a1(IV) chain (Lauer-Fields et al., 2003). In addition, three heparin-binding sequences have also been found in the triple-helical and NC1 domains of a1(IV) and a2(IV) chains (Koliakos et al., 1989). A synthetic peptide (TAGSCLRKFSTM) corresponding to a sequence from a1(IV) NC1 domain has been shown to promote adhesion and spreading of endothelial cells (Tsilibary et al., 1990). Another heparin-binding peptide, Hep-III (GEFYFDLRLKGDK), derived from the interruption of a 1 chain promoted adhesion of keratinocytes and mesangial cells (Setty et al., 1998; Wilke and Furcht, 1990). Interestingly, the same peptide mediates binding of $\alpha_{3} \beta_{1}$ integrin and may also interact with $\alpha_{2} \beta_{1}$ integrin depending on integrin expression levels (Kim et al., 1994; Setty et al., 1998). However, the degree of cell spreading on Hep-III is significantly lower than on full-length type IV collagen or its triple-helical domain, and Hep-III only partially inhibited cell motility on collagen IV, indicating rather limited contribution of proteoglycans to mechanisms of cell adhesion and migration. 
Another group of collagen-binding proteins called discoidin domain receptors (DDRs) has recently been discovered (Shrivastava et al., 1997; Vogel et al., 1997). DDRs belong to the large family of receptor tyrosine kinases, and two members of this family, DDR1 and DDR2, are widely expressed in mammalian cells. Their most distinctive feature is the stimulation of tyrosine kinase activity by native triple-helical collagens that sustain over an extended period of time. Interestingly, collagen IV stimulates phosphorylation of DDR1, but not DDR2. Activation of DDR1 was not affected in the $\beta_{1}$ integrin null cells, suggesting that DDR1 represents independent receptor directly interacting with collagen (Vogel et al., 2000). This does not exclude a possibility of further downstream crosstalk between integrin and DDR signaling pathways. Deletion of DDR1 led to decreased collagen adhesion, migration of vascular smooth muscle cells, and enhanced proliferation of mesangial cells (Curat and Vogel, 2002; Hou et al., 2001). In addition, DDR1 knockout mice develop localized thickening of GBM and proteinuria, suggesting that collagen IV-DDR1 interaction plays an important role for structural integrity and filtration function in the kidney (Gross et al., 2004).

\section{Genetic and Acquired Diseases of Collagen IV}

Collagen IV is involved in a number of genetic and acquired disorders. Depending on genetic and nongenetic factors including alterations in temporal and spatial gene expression, splice variations, posttranslational modifications, and the chain-specific assembly of particular a-chains, different organs can be affected during the development and in the adult life span. Among these organs, the kidney has shown to be particularly affected by collagen IV abnormalities. Because of its highly specialized features, the BM of the renal glomerulus plays a critical role in filtration of the circulating plasma. As all the six collagen IV genes are differentially expressed in different anatomical parts of the glomerulus, and since lack of one gene product can not be compensated by another, renal disorders of collagen IV are the most life-threatening disorders leading to end-stage-renal-disease (ESRD) and mortality. Alport's and Goodpasture's syndromes are the two major examples of the kidney abnormalities in which collagen IV is the central molecule directly involved in the pathogenesis, and thus will be discussed here.

\section{Alport's Syndrome}

In 1927, Arthur Cecil Alport described the clinical syndrome of a hereditary nephritis characterized by hematuria and sensorineural deafness (Alport, 1927). For decades, the syndrome was diagnosed solely based on its clinical manifestations. However, with advances in electron microscopy in the early 1970s, the underlying pathological clues to the renal dysfunction, which was ultrastructural changes with regional thinning and thickening of the GBM, were reported from several laboratories (Churg and Sherman, 1973; Hinglais et al., 1972; Kinoshita et al., 1969; Spear and Slusser, 1972). The presence of a unique collagen in the GBM had already been reported by Kefalides in the late 60s (Kefalides, 1966, 1968), and it was thought to consist of three identical a-chains forming the scaffold of the GBM (Kefalides, 1971). This inspired Spear to suggest that mutations in the gene for this unique structural GBM component could cause Alport's syndrome (Spear, 1973). However, it was not until 1990 that the genetic basis for what came to be known as X-linked 
Alport's syndrome was described (Barker et al., 1990; Hostikka et al., 1990; Myers et al., 1990; Pihlajaniemi et al., 1990). Since then, a large number of different mutations in the COL4A5 gene as well as in the COL4A3 and COL4A4 genes have been reported (Jais et al., 2000, 2003; Longo et al., 2002). These mutations not only include nonsense and missense mutations, but also mutations that affect splicing, stability of triple-helical structure, posttranslational modifications, and the assembly of chains into heterotrimeric molecules. While mutations in the COL4A3 or COL4A4 genes cause autosomal recessive form of the syndrome affecting both males and females equally (Lemmink et al., 1994; Mochizuki et al., 1994), $\sim 85 \%$ of patients with Alport's syndrome carrying mutations in the COL4A5 gene and therefore are classified as X-linked with the highest prevalence in males (Barker et al., 1990; Martin et al., 1998).

The expression of genes encoding the a3(IV), a4(IV), and a5(IV) are subjected to developmental switch in the GBM. Thus, disregard of which gene is affected mutations that alter normal expression, posttranslational modifications or assembly of the a $3 a 4 a 5$ triplehelical molecule will cause an arrest in the developmental switch and persistence of the a1a1a2 network in the GBM with Alport's syndrome as consequence. Differences in the physical and biological properties between the classical a1a1a2 network and the a3a4a5 network are most likely to underlie the disability of the former network to compensate for the lack of the latter in the Alport's syndrome patients. Relative to a 1a1a2 network, the a3a4a5 network is highly crosslinked because of its larger degree of inter- and intrachain disulfide bonds and has different physical properties than the classical a1a1a2 network (Gunwar et al., 1998). During the embryonic development of the kidney and the increased plasma filtration cross the glomerular capillaries, the levels of circulating proteins including serum proteases constantly increases. The higher susceptibility of the embryonic a1a1a2 network to proteolytic activities makes the developmental switch to the more resistant a $3 a 4 a 5$ network necessary to withstand higher glomerular pressure and proteolytic degradation of the GBM. Patients with Alport's syndrome probably become more sensitive to gradual proteolytic degradation resulting in uneven thickness of the GBM characterized in all renal samples of Alport's syndrome patients.

Patients with Alport's syndrome can benefit from renal transplantation as the development of nephritis due to generation of alloantibodies is not very common. Sensitive assays have shown that the posttransplant alloantibodies are always directed against multiple epitopes along the a3(IV), a4(IV), or a5(IV) chains (Hudson et al., 1992; Kalluri et al., 2000). Circulation of such antibodies is a characteristic feature of another collagen IV-related renal disease known as Goodpasture's syndrome.

\section{Goodpasture's Syndrome}

Goodpasture's syndrome is an autoimmune disease characterized by a rapidly progressive glomerulonephritis which is often associated with lung hemorrhage. The disease, which occurs primarily in young men usually in their late 20 s and in both men and women in their $60 \mathrm{~s}$, is caused by circulating autoantibodies directed to specific epitopes located on the a3(IV) NC1 domain (Saus et al., 1988; Wieslander et al., 1984). Although immunoreactivity to epitopes located on the $\mathrm{NC1}$ domains of other collagen IV chains have been reported, 
almost all anti-GBM antibodies from patients are reactive to the a3(IV) NC1 domain (Kalluri et al., 1995). In this regard, the immunospecificity of antibodies to a3(IV) NC1 domain is puzzling, since antibodies to NC1 domains of other chains, such as a1(IV) and a2(IV), do not cause anti-GBM nephritis (Bolton et al., 1995; Kalluri et al., 1996; Sado et al., 1998). Genetic factors have been reported indicating that patients with certain allelic variations (HLA-DRB1*1501 and DRB1*1502) have increased susceptibility to develop the disease, whereas other alleles (HLA-DR7 and DR1) are protective (Phelps and Rees, 1999). The role of autoreactive CD4+ Tcells in mediating the disease has been reported, clearly indicating the importance of cell-mediated autoimmunity in the pathogenesis (Salama et al., 2001; Wong et al., 2001).

The pathogenesis of Goodpasture's syndrome is characterized by glomerulonephritis which is initiated via high-affinity autoantibodies, usually of the IgG class. Two dominant epitopes $\left(\mathrm{E}_{\mathrm{A}}\right.$ and $\mathrm{E}_{\mathrm{B}}$ ) within the a3(IV) NC1 domain have been identified (Borza et al., 2000; David et al., 2001; Gunnarsson et al., 2000; Hellmark et al., 1999; Netzer et al., 1999). Located in close proximity to each other and near the triple-helical junction (Fig. 2), these epitopes do not normally show reactivity with the antibodies unless the $\mathrm{NC} 1$ hexamer is dissociated (Borza et al., 2002). Therefore, it is presumed that environmental factors such as exposure to hydrocarbons or tobacco smoke may be needed to reveal the cryptic epitopes to the immune system (Donaghy and Rees, 1983; Stevenson et al., 1995). Disregard of the cause, binding of immunoglobulins to the GBM activates the complement system and a cascade of proteases, which results in disruption of the glomerular filtration barrier followed by proteinuria and formation of glomerular crescent. The cell-mediated immunoreactivity by CD4+ and CD8+ $\mathrm{T}$ cells is soon followed by migration of macrophages and neutrophils into the glomerulus causing further inflammation and increased proteinuria which lead to interstitial nephritis (Kitching et al., 2002; Remuzzi and Bertani, 1998; Timoshanko et al., 2001; Wu et al., 2001, 2002).

Treatments for Goodpasture's patients are limited to plasmapheresis which removes the harmful antibodies from the circulations and/or immunosuppression. Kidney transplantation is possible, however, because there is a risk for recurrence the procedure should wait until anti-GBM antibodies are undetectable in the serum (Netzer et al., 1998a).

\section{Rare Genetic Disorders of Collagen IV}

Recently, it was shown that mutations in the COLAAl gene causes type 1 or encephaloclastic porencephaly, which is a rare neurological disease typically manifested in infants (Gould et al., 2005). The disease is characterized by the presence of degenerative cavities and cerebral lesions in the brain leading to severe pathological disorders such as poor speech development, epilepsy, mental retardation, and cerebral palsy (Pasternak et al., 1980). Using a mouse model generated by random mutagenesis, Gould et al. characterized a novel mouse mutant with severe perinatal cerebral hemorrhage similar to those previously described in a large human family with autosomal dominant type 1 porencephaly (Aguglia et al., 2004; Smit et al., 1984). The causative gene in the mouse mutant was mapped and identified as COLAA1 gene. Sequence analysis revealed that a splice site mutation which resulted in excision of an exon generated a semidominant mutant a1(IV) chain, which upon assembly 
inhibited secretion of the wild-type and mutant collagen IV (Gould et al., 2005). Electron micrographs of the mutant mice clearly demonstrated structural defects in the cerebral vasculature such as uneven BMs with variable thickness, inconsistent density, focal disruptions, and herniation which presumably reflect a weaker BM structure. Because not all mutant mice developed porencephaly, the authors proposed that in addition to the mutations environmental factors such as birth trauma may be needed to cause the disease (Gould et al., 2005).

The above finding tempted the authors to investigate potential mutations in the human COLAAl gene in two ethnically separate families with autosomal dominant porencephaly. Sequence analysis revealed two mutations (Gly to Arg and Gly to Ser) leading to replacement of a conserved Gly residue in the Gly-Xaa-Yaa repeats of the triple-helical collagenous domain. Such mutations are known to disrupt the triple-helical formation during the assembly of collagens leading to protein defect (Engel and Prockop, 1991). Interestingly, in addition to porencephaly, one of the adult patients was found to suffer from recurrent hemorrhagic strokes cased by weakened vascular BM. This finding indicates that such dominant mutations in the COLAAl gene may also contribute to hemorrhagic stroke in adults (Gould et al., 2005). Indeed, such indications have been reported in an adult patient with autosomal dominant porencephaly who showed only minor neurological dysfunction, but suffered from recurrent strokes (van der Knaap et al., 2006). These findings suggest that certain mutations or polymorphisms in the COLAA1, COLAA2, or the genes encoding other $\mathrm{BM}$ components may conspire with environmental factors to underlie recurrent hemorrhagic strokes in adults.

\section{Conclusion}

Four decades after its discovery, collagen IV is still the focus of extensive research from biochemistry to pathology and genetic disorders. Being the only collagen type encoded by six different genes, the six a-chains of collagen IV can recognize each other with a remarkable specificity and assemble into unique heterotrimers. After secretion into the ECM, these molecules further interact to form higher supramolecular organizations which together with other proteins finally form unique BMs in a tissue-specific manner. Through interactions with specific cellular receptors such as integrins, the BM collagen IV networks not only provide structural support to the cells and tissues, but they also affect the biological fate during and after the development. As new discoveries keep unraveling mysteries about the genetic mutations, biosynthesis, molecular assembly, and network formation of collagen IV, our understanding has dramatically increased about the critical role of these complex supramolecular structures in health and disease.

\section{Acknowledgments}

Contract grant sponsor: National Institutes of Health; Contract grant number: R-37DK18381. 


\section{References}

Abecassis J, Millon-Collard R, Klein-Soyer C, Nicora F, Fricker JP, Beretz A, Eber M, Muller D, Cazenave JP. Adhesion of human breast cancer cell line MCF-7 to human vascular endothelial cells in culture. Enhancement by activated platelets. Int J Cancer. 1987; 40:525-531. [PubMed: 3666990]

Aguglia U, Gambardella A, Breedveld GJ, Oliveri RL, Le Piane E, Messina D, Quattrone A, Heutink P. Suggestive evidence for linkage to chromosome 13qter for autosomal dominant type 1 porencephaly. Neurology. 2004; 62:1613-1615. [PubMed: 15136694]

Alport AC. Hereditary familial congenital haemorrhagic nephritis. Br Med J. 1927; 1:504-506. [PubMed: 20773074]

Aumailley M, Timpl R. Attachment of cells to basement membrane collagen type IV. J Cell Biol. 1986; 103:1569-1575. [PubMed: 3771647]

Aumailley M, Gayraud B. Structure and biological activity of the extracellular matrix. J Mol Med. 1998; 76:253-265. [PubMed: 9535559]

Barker DF, Hostikka SL, Zhou J, Chow LT, Oliphant AR, Gerken SC, Gregory MC, Skolnick MH, Atkin CL, Tryggvason K. Identification of mutations in the COL4A5 collagen gene in Alport syndrome. Science. 1990; 248:1224-1227. [PubMed: 2349482]

Bernal D, Quinones S, Saus J. The human mRNA encoding the Goodpasture antigen is alternatively spliced. J Biol Chem. 1993; 268:12090-12094. [PubMed: 8505332]

Bolton WK, Luo AM, Fox PL, May WJ, Sturgill BC. Study of EHS type IV collagen lacking Goodpasture's epitope in glomerulonephritis in rats. Kidney Int. 1995; 47:404-410. [PubMed: 7536854]

Borza DB, Netzer KO, Leinonen A, Todd P, Cervera J, Saus J, Hudson BG. The Goodpasture autoantigen: Identification of multiple cryptic epitopes on the $\mathrm{NC1}$ domain of the a3(IV) collagen chain. J Biol Chem. 2000; 275:6030-6037. [PubMed: 10681598]

Borza DB, Bondar O, Ninomiya Y, Sado Y, Naito I, Todd P, Hudson BG. The NC1 domain of collagen IV encodes a novel network composed of the a1, a2, a5, and a6 chains in smooth muscle basement membranes. J Biol Chem. 2001; 276:28532-28540. [PubMed: 11375996]

Borza DB, Bondar O, Todd P, Sundaramoorthy M, Sado Y, Ninomiya Y, Hudson BG. Quaternary organization of the Goodpasture autoantigen, the a3(IV) collagen chain. Sequestration of two cryptic autoepitopes by intrapromoter interactions with the a 4 and a $5 \mathrm{NC} 1$ domains. J Biol Chem. 2002; 277:40075-40083. [PubMed: 12193605]

Boutaud A, Borza DB, Bondar O, Gunwar S, Netzer KO, Singh N, Ninomiya Y, Sado Y, Noelken ME, Hudson BG. Type IV collagen of the glomerular basement membrane: Evidence that the chain specificity of network assembly is encoded by the noncollagenous NC1 domains. J Biol Chem. 2000; 275:30716-30724. [PubMed: 10896941]

Brodsky B, Shah NK. Protein motifs. 8. The triple-helix motif in proteins. FASEB J. 1995; 9:15371546. [PubMed: 8529832]

Brodsky B, Ramshaw JA. The collagen triple-helix structure. Matrix Biol. 1997; 15:545-554. [PubMed: 9138287]

Butkowski RJ, Wieslander J, Wisdom BJ, Barr JF, Noelken ME, Hudson BG. Properties of the globular domain of type IV collagen and its relationship to the Goodpasture antigen. J Biol Chem. 1985; 260:3739-3747. [PubMed: 2982876]

Butkowski RJ, Langeveld JP, Wieslander J, Hamilton J, Hudson BG. Localization of the Goodpasture epitope to a novel chain of basement membrane collagen. J Biol Chem. 1987; 262:7874-7877. [PubMed: 2438283]

Butkowski RJ, Shen GQ, Wieslander J, Michael AF, Fish AJ. Characterization of type IV collagen $\mathrm{NC} 1$ monomers and Goodpasture antigen in human renal basement membranes. J Lab Clin Med. 1990; 115:365-373. [PubMed: 1690255]

Chelberg MK, Tsilibary EC, Hauser AR, McCarthy JB. Type IV collagen-mediated melanoma cell adhesion and migration: Involvement of multiple, distinct domains of the collagen molecule. Cancer Res. 1989; 49:4796-4802. [PubMed: 2758412] 
Cheng YF, Kramer RH. Human microvascular endothelial cells express integrin-related complexes that mediate adhesion to the extracellular matrix. J Cell Physiol. 1989; 139:275-286. [PubMed: 2469686]

Churg J, Sherman RL. Pathologic characteristics of hereditary nephritis. Arch Pathol. 1973; 95:374379. [PubMed: 4701392]

Colorado PC, Torre A, Kamphaus G, Maeshima Y, Hopfer H, Takahashi K, Volk R, Zamborsky ED, Herman S, Sarkar PK, Ericksen MB, Dhanabal M, Simons M, Post M, Kufe DW, Weichselbaum RR, Sukhatme VP, Kalluri R. Anti-angiogenic cues from vascular basement membrane collagen. Cancer Res. 2000; 60:2520-2526. [PubMed: 10811134]

Curat CA, Vogel WF. Discoidin domain receptor 1 controls growth and adhesion of mesangial cells. J Am Soc Nephrol. 2002; 13:2648-2656. [PubMed: 12397034]

David M, Borza DB, Leinonen A, Belmont JM, Hudson BG. Hydrophobic amino acid residues are critical for the immunodominant epitope of the Goodpasture autoantigen. A molecular basis for the cryptic nature of the epitope. J Biol Chem. 2001; 276:6370-6377. [PubMed: 11098057]

de Melker AA, Sonnenberg A. Integrins: Alternative splicing as a mechanism to regulate ligand binding and integrin signaling events. Bioessays. 1999; 21:499-509. [PubMed: 10402956]

Dedhar S, Saulnier R, Nagle R, Overall CM. Specific alterations in the expression of a $\beta 1$ and a6 $\beta 4$ integrins in highly invasive and metastatic variants of human prostate carcinoma cells selected by in vitro invasion through reconstituted basement membrane. Clin Exp Metastasis. 1993; 11:391400. [PubMed: 8375114]

Delwel GO, de Melker AA, Hogervorst F, Jaspars LH, Fles DL, Kuikman I, Lindblom A, Paulsson M, Timpl R, Sonnenberg A. Distinct and overlapping ligand specificities of the a3A $\beta 1$ and $a 6 \mathrm{~A} \beta 1$ integrins: Recognition of laminin isoforms. Mol Biol Cell. 1994; 5:203-215. [PubMed: 8019006]

Dolz R, Engel J, Kuhn K. Folding of collagen IV. Eur J Biochem. 1988; 178:357-366. [PubMed: 2850175]

Donaghy M, Rees AJ. Cigarette smoking and lung haemorrhage in glomerulonephritis caused by autoantibodies to glomerular basement membrane. Lancet. 1983; 2:1390-1393. [PubMed: 6140495]

Eble JA, Golbik R, Mann K, Kuhn K. The a $1 \beta 1$ integrin recognition site of the basement membrane collagen molecule [a1(IV)]2 a2(IV). EMBO J. 1993; 12:4795-4802. [PubMed: 8223488]

Eble JA, Wucherpfennig KW, Gauthier L, Dersch P, Krukonis E, Isberg RR, Hemler ME. Recombinant soluble human a3 $\beta 1$ integrin: Purification, processing, regulation, and specific binding to laminin-5 and invasin in a mutually exclusive manner. Biochemistry. 1998; 37:1094510955. [PubMed: 9692987]

Elices MJ, Urry LA, Hemler ME. Receptor functions for the integrin VLA-3: Fibronectin, collagen, and laminin binding are differentially influenced by Arg-Gly-Asp peptide and by divalent cations. J Cell Biol. 1991; 112:169-181. [PubMed: 1986004]

Engel J, Prockop DJ. The zipper-like folding of collagen triple helices and the effects of mutations that disrupt the zipper. Annu Rev Biophys Biophys Chem. 1991; 20:137-152. [PubMed: 1867713]

Engvall E, Ruoslahti E. Binding of soluble form of fibroblast surface protein, fibronectin, to collagen. Int J Cancer. 1977; 20:1-5. [PubMed: 903179]

Feng L, Xia Y, Wilson CB. Alternative splicing of the NC1 domain of the human a3(IV) collagen gene. Differential expression of mRNA transcripts that predict three protein variants with distinct carboxyl regions. J Biol Chem. 1994; 269:2342-2348. [PubMed: 8294492]

Fessler LI, Fessler JH. Identification of the carboxyl peptides of mouse procollagen IV and its implications for the assembly and structure of basement membrane procollagen. J Biol Chem. 1982; 257:9804-9810. [PubMed: 6809743]

Gardner H, Kreidberg J, Koteliansky V, Jaenisch R. Deletion of integrin a1 by homologous recombination permits normal murine development but gives rise to a specific deficit in cell adhesion. Dev Biol. 1996; 175:301-313. [PubMed: 8626034]

Gould DB, Phalan FC, Breedveld GJ, van Mil SE, Smith RS, Schimenti JC, Aguglia U, van der Knaap MS, Heutink P, John SW. Mutations in Col4a1 cause perinatal cerebral hemorrhage and porencephaly. Science. 2005; 308:1167-1171. [PubMed: 15905400] 
Green LJ, Mould AP, Humphries MJ. The integrin $\beta$-subunit. Int J Biochem Cell Biol. 1998; 30:179_ 184. [PubMed: 9608671]

Gross O, Beirowski B, Harvey SJ, McFadden C, Chen D, Tam S, Thorner PS, Smyth N, Addicks K, Bloch W, Ninomiya Y, Sado Y, Weber M, Vogel WF. DDR1-deficient mice show localized subepithelial GBM thickening with focal loss of slit diaphragms and proteinuria. Kidney Int. 2004; 66:102-111. [PubMed: 15200417]

Gunnarsson A, Hellmark T, Wieslander J. Molecular properties of the Goodpasture epitope. J Biol Chem. 2000; 275:30844-30848. [PubMed: 10896942]

Gunwar S, Saus J, Noelken ME, Hudson BG. Glomerular basement membrane. Identification of a fourth chain, a4, of type IV collagen. J Biol Chem. 1990; 265:5466-5469. [PubMed: 2318822]

Gunwar S, Ballester F, Noelken ME, Sado Y, Ninomiya Y, Hudson BG. Glomerular basement membrane. Identification of a novel disulfide-cross-linked network of a3, a4 and a5 chains of type IV collagen and its implications for the pathogenesis of Alport syndrome. J Biol Chem. 1998; 273:8767-8775. [PubMed: 9535854]

Han J, Ohno N, Pasco S, Monboisse JC, Borel JP, Kefalides NA. A cell binding domain from the a3 chain of type IV collagen inhibits proliferation of melanoma cells. J Biol Chem. 1997; 272:2039520401. [PubMed: 9252346]

Heikkila P, Soininen R. The type IV collagen gene family. Contrib Nephrol. 1996; 117:105-29. [PubMed: 8801041]

Hellmark T, Burkhardt H, Wieslander J. Goodpasture disease. Characterization of a single conformational epitope as the target of pathogenic autoantibodies. J Biol Chem. 1999; 274:2586225868. [PubMed: 10464328]

Herbst TJ, McCarthy JB, Tsilibary EC, Furcht LT. Differential effects of laminin, intact type IV collagen, and specific domains of type IV collagen on endothelial cell adhesion and migration. $\mathrm{J}$ Cell Biol. 1988; 106:1365-1373. [PubMed: 3360855]

Hinglais N, Grunfeld JP, Bois E. Characteristic ultrastructural lesion of the glomerular basement membrane in progressive hereditary nephritis (Alport's syndrome). Lab Invest. 1972; 27:473-487. [PubMed: 4653971]

Hodivala-Dilke KM, DiPersio CM, Kreidberg JA, Hynes RO. Novel roles for a $3 \beta 1$ integrin as a regulator of cytoskeletal assembly and as a trans-dominant inhibitor of integrin receptor function in mouse keratinocytes. J Cell Biol. 1998; 142:1357-1369. [PubMed: 9732295]

Hostikka SL, Eddy RL, Byers MG, Hoyhtya M, Shows TB, Tryggvason K. Identification of a distinct type IV collagen a-chain with restricted kidney distribution and assignment of its gene to the locus of X chromosome-linked Alport syndrome. Proc Natl Acad Sci USA. 1990; 87:1606-1610. [PubMed: 1689491]

Hou G, Vogel W, Bendeck MP. The discoidin domain receptor tyrosine kinase DDR1 in arterial wound repair. J Clin Invest. 2001; 107:727-735. [PubMed: 11254672]

Hudson BG. The molecular basis of Goodpasture and Alport syndromes: Beacons for the discovery of the collagen IV family. J Am Soc Nephrol. 2004; 15:2514-2527. [PubMed: 15466256]

Hudson BG, Kalluri R, Gunwar S, Weber M, Ballester F, Hudson JK, Noelken ME, Sarras M, Richardson WR, Saus J, Abrahamson DR, Glick AD, Haralson MA, Helderman JH, Stone WJ, Jacobson HR. The pathogenesis of Alport syndrome involves type IV collagen molecules containing the a3(IV) chain: evidence from anti-GBM nephritis after renal transplantation. Kidney Int. 1992; 42:179-187. [PubMed: 1635348]

Hudson BG, Kalluri R, Gunwar S, Noelken ME. Structure and organization of type IV collagen of renal glomerular basement membrane. Contrib Nephrol. 1994; 107:163-7. [PubMed: 8004963]

Hudson BG, Tryggvason K, Sundaramoorthy M, Neilson EG. Alport's syndrome, Goodpasture's syndrome, and type IV collagen. N Engl J Med. 2003; 348:2543-2556. [PubMed: 12815141]

Humphries JD, Byron A, Humphries MJ. Integrin ligands at a glance. J Cell Sci. 2006; 119(Part 19): 3901-3903. [PubMed: 16988024]

Hynes RO. Integrins: A family of cell surface receptors. Cell. 1987; 48:549-554. [PubMed: 3028640]

Hynes RO. Integrins: Versatility, modulation, and signaling in cell adhesion. Cell. 1992; 69:11-25. [PubMed: 1555235] 
Hynes RO. Integrins: Bidirectional, allosteric signaling machines. Cell. 2002; 110:673-687. [PubMed: 12297042]

Jais JP, Knebelmann B, Giatras I, De Marchi M, Rizzoni G, Renieri A, Weber M, Gross O, Netzer KO, Flinter F, Pirson Y, Verellen C, Wieslander J, Persson U, Tryggvason K, Martin P, Hertz JM, Schroder C, Sanak M, Krejcova S, Carvalho MF, Saus J, Antignac C, Smeets H, Gubler MC. Xlinked Alport syndrome: Natural history in 195 families and genotype-phenotype correlations in males. J Am Soc Nephrol. 2000; 11:649-657. [PubMed: 10752524]

Jais JP, Knebelmann B, Giatras I, De Marchi M, Rizzoni G, Renieri A, Weber M, Gross O, Netzer KO, Flinter F, Pirson Y, Dahan K, Wieslander J, Persson U, Tryggvason K, Martin P, Hertz JM, Schroder C, Sanak M, Carvalho MF, Saus J, Antignac C, Smeets H, Gubler MC. X-linked Alport syndrome: Natural history and genotype-phenotype correlations in girls and women belonging to 195 families: A "European Community Alport Syndrome Concerted Action" study. J Am Soc Nephrol. 2003; 14:2603-2610. [PubMed: 14514738]

Jenkins CL, Raines RT. Insights on the conformational stability of collagen. Nat Prod Rep. 2002; 19:49-59. [PubMed: 11902439]

Kaido T, Yebra M, Cirulli V, Montgomery AM. Regulation of human $\beta$-cell adhesion, motility, and insulin secretion by collagen IV and its receptor a1ß1. J Biol Chem. 2004; 279:53762-53769. [PubMed: 15485856]

Kalluri R, Wilson CB, Weber M, Gunwar S, Chonko AM, Neilson EG, Hudson BG. Identification of the a 3 chain of type IV collagen as the common autoantigen in antibasement membrane disease and Goodpasture syndrome. J Am Soc Nephrol. 1995; 6:1178-1185. [PubMed: 8589284]

Kalluri R, Petrides S, Wilson CB, Tomaszewski JE, Palevsky HI, Grippi MA, Madaio MP, Neilson EG. Anti-a1(IV) collagen autoantibodies associated with lung adenocarcinoma presenting as the Goodpasture syndrome. Ann Intern Med. 1996; 124:651-653. [PubMed: 8607593]

Kalluri R, Torre A, Shield CF III, Zamborsky ED, Werner MC, Suchin E, Wolf G, Helmchen UM, van den Heuvel LP, Grossman R, Aradhye S, Neilson EG. Identification of a3, a4, and a 5 chains of type IV collagen as alloantigens for Alport posttransplant anti-glomerular basement membrane antibodies. Transplantation. 2000; 69:679-683. in process citation. [PubMed: 10708133]

Keely PJ, Fong AM, Zutter MM, Santoro SA. Alteration of collagen-dependent adhesion, motility, and morphogenesis by the expression of antisense a 2 integrin mRNA in mammary cells. J Cell Sci. 1995; 108(Part 2):595-607. [PubMed: 7769004]

Kefalides NA. A collagen of unusual composition and a glycoprotein isolated from canine glomerular basement membrane. Biochem Biophys Res Commun. 1966; 22:26-32. [PubMed: 5937334]

Kefalides NA. Isolation and characterization of the collagen from glomerular basement membrane. Biochemistry. 1968; 7:3103-3112. [PubMed: 5684337]

Kefalides NA. Isolation of collagen from basement membranes containing three identical chains. Biochem Biophys Res Commun. 1971; 45:226-234. [PubMed: 4946405]

Kern A, Eble J, Golbik R, Kuhn K. Interaction of type IV collagen with the isolated integrins a1 $\beta 1$ and a2 $\beta 1$. Eur J Biochem. 1993; 215:151-159. [PubMed: 8344274]

Khoshnoodi J, Cartailler JP, Alvares K, Veis A, Hudson BG. Molecular recognition in the assembly of collagens: Terminal non-collagenous domains are key recognition modules in the formation of triple helical protomers. J Biol Chem. 2006a; 281:38117-38121. [PubMed: 17082192]

Khoshnoodi J, Sigmundsson K, Cartailler JP, Bondar O, Sundaramoorthy M, Hudson BG. Mechanism of chain selection in the assembly of collagen IV: A prominent role for the $\{a\} 2$ chain. J Biol Chem. 2006b; 281:6058-6069. [PubMed: 16373348]

Kim JP, Chen JD, Wilke MS, Schall TJ, Woodley DT. Human keratinocyte migration on type IV collagen. Roles of heparin-binding site and a $2 \beta 1$ integrin. Lab Invest. 1994; 71:401-408. [PubMed: 7933990]

Kinoshita Y, Osawa G, Morita T, Kobayashi N, Wada J. Hereditary chronic nephritis (Alport) complicated by nephrotic syndrome. Light, fluorescent and electron microscopic studies of renal biopsy specimens. Acta Med Biol (Niigata). 1969; 17:101-117. [PubMed: 5349568]

Kitching AR, Ru Huang X, Turner AL, Tipping PG, Dunn AR, Holds-worth SR. The requirement for granulocyte-macrophage colony-stimulating factor and granulocyte colony-stimulating factor in 
leukocyte-mediated immune glomerular injury. J Am Soc Nephrol. 2002; 13:350-358. [PubMed: 11805162]

Kleppel MM, Michael AF, Fish AJ. Antibody specificity of human glomerular basement membrane type IV collagen NC1 subunits. Species variation in subunit composition. J Biol Chem. 1986; 261:16547-16552. [PubMed: 3782134]

Knight CG, Morton LF, Onley DJ, Peachey AR, Messent AJ, Smethurst PA, Tuckwell DS, Farndale RW, Barnes MJ. Identification in collagen type I of an integrin a $2 \beta 1$-binding site containing an essential GER sequence. J Biol Chem. 1998; 273:33287-33294. [PubMed: 9837901]

Knight CG, Morton LF, Peachey AR, Tuckwell DS, Farndale RW, Barnes MJ. The collagen-binding A-domains of integrins $\alpha(1) \beta(1)$ and $\alpha(2) \beta(1)$ recognize the same specific amino acid sequence, GFOGER, in native (triple-helical) collagens. J Biol Chem. 2000; 275:35-40. [PubMed: 10617582]

Knutson JR, Iida J, Fields GB, McCarthy JB. CD44/chondroitin sulfate proteoglycan and a2 $\beta 1$ integrin mediate human melanoma cell migration on type IV collagen and invasion of basement membranes. Mol Biol Cell. 1996; 7:383-396. [PubMed: 8868467]

Koliakos GG, Kouzi-Koliakos K, Furcht LT, Reger LA, Tsilibary EC. The binding of heparin to type IV collagen: Domain specificity with identification of peptide sequences from the $\alpha 1$ (IV) and a2(IV) which preferentially bind heparin. J Biol Chem. 1989; 264:2313-2323. [PubMed: 2914908]

Kramer RH, Marks N. Identification of integrin collagen receptors on human melanoma cells. J Biol Chem. 1989; 264:4684-8. [PubMed: 2538453]

Langeveld JP, Wieslander J, Timoneda J, McKinney P, Butkowski RJ, Wisdom BJ Jr, Hudson BG. Structural heterogeneity of the noncollagenous domain of basement membrane collagen. J Biol Chem. 1988; 263:10481-10488. [PubMed: 3392020]

Langeveld JP, Noelken ME, Hard K, Todd P, Vliegenthart JF, Rouse J, Hudson BG. Bovine glomerular basement membrane. Location and structure of the asparagine-linked oligosaccharide units and their potential role in the assembly of the 7S collagen IV tetramer. J Biol Chem. 1991; 266:2622-2631. [PubMed: 1990011]

Lauer-Fields JL, Malkar NB, Richet G, Drauz K, Fields GB. Melanoma cell CD44 interaction with the a1(IV)1263-1277 region from basement membrane collagen is modulated by ligand glycosylation. J Biol Chem. 2003; 278:14321-14330. [PubMed: 12574156]

Lauer JL, Gendron CM, Fields GB. Effect of ligand conformation on melanoma cell a3 $\beta 1$ integrinmediated signal transduction events: Implications for a collagen structural modulation mechanism of tumor cell invasion. Biochemistry. 1998; 37:5279-5287. [PubMed: 9548759]

Lein PJ, Higgins D, Turner DC, Flier LA, Terranova VP. The NC1 domain of type IV collagen promotes axonal growth in sympathetic neurons through interaction with the a $1 \beta 1$ integrin. J Cell Biol. 1991; 113:417-428. [PubMed: 2010469]

Leinonen A, Mariyama M, Mochizuki T, Tryggvason K, Reeders ST. Complete primary structure of the human type IV collagen a4(IV) chain. Comparison with structure and expression of the other a (IV) chains. J Biol Chem. 1994; 269:26172-26177. [PubMed: 7523402]

Leitinger B, Hohenester E. Mammalian collagen receptors. Matrix Biol. 2007; 26:146-155. [PubMed: 17141492]

Lemmink HH, Mochizuki T, van den Heuvel LP, Schroder CH, Barrientos A, Monnens LA, van Oost BA, Brunner HG, Reeders ST, Smeets HJ. Mutations in the type IV collagen a3 (COL4A3) gene in autosomal recessive Alport syndrome. Hum Mol Genet. 1994; 3:1269-1273. [PubMed: 7987301]

Leung-Hagesteijn CY, Milankov K, Michalak M, Wilkins J, Dedhar S. Cell attachment to extracellular matrix substrates is inhibited upon downregulation of expression of calreticulin, an intracellular integrin a-subunit-binding protein. J Cell Sci. 1994; 107(Part 3):589-600. [PubMed: 8006073]

Longo I, Porcedda P, Mari F, Giachino D, Meloni I, Deplano C, Brusco A, Bosio M, Massella L, Lavoratti G, Roccatello D, Frasca G, Mazzucco G, Muda AO, Conti M, Fasciolo F, Arrondel C, Heidet L, Renieri A, De Marchi M. COL4A3/COL4A4 mutations: From familial hematuria to autosomal-dominant or recessive Alport syndrome. Kidney Int. 2002; 61:1947-1956. [PubMed: 12028435] 
Maeshima Y, Colorado PC, Kalluri R. Two RGD-independent av $\beta 3$ integrin binding sites on tumstatin regulate distinct anti-tumor properties. J Biol Chem. 2000a; 275:23745-26750. [PubMed: 10837460]

Maeshima Y, Colorado PC, Torre A, Holthaus KA, Grunkemeyer JA, Ericksen MB, Hopfer H, Xiao Y, Stillman IE, Kalluri R. Distinct antitumor properties of a type IV collagen domain derived from basement membrane. J Biol Chem. 2000b; 275:21340-21348. [PubMed: 10766752]

Maeshima Y, Manfredi M, Reimer C, Holthaus KA, Hopfer H, Chandamuri BR, Kharbanda S, Kalluri $\mathrm{R}$. Identification of the anti-angiogenic site within vascular basement membrane-derived tumstatin. J Biol Chem. 2001a; 276:15240-15248. [PubMed: 11278365]

Maeshima Y, Yerramalla UL, Dhanabal M, Holthaus KA, Barbashov S, Kharbanda S, Reimer C, Manfredi M, Dickerson WM, Kalluri R. Extracellular matrix-derived peptide binds to a(v) $\beta(3)$ integrin and inhibits angiogenesis. J Biol Chem. 2001b; 276:31959-31968. [PubMed: 11399763]

Maeshima Y, Sudhakar A, Lively JC, Ueki K, Kharbanda S, Kahn CR, Sonenberg N, Hynes RO, Kalluri R. Tumstatin, an endothelial cell-specific inhibitor of protein synthesis. Science. 2002; 295:140-143. [PubMed: 11778052]

Mariyama M, Kalluri R, Hudson BG, Reeders ST. The a4(IV) chain of basement membrane collagen. Isolation of cDNAs encoding bovine $\mathrm{a} 4(\mathrm{IV})$ and comparison with other type IV collagens. J Biol Chem. 1992; 267:1253-1258. [PubMed: 1370461]

Mariyama M, Leinonen A, Mochizuki T, Tryggvason K, Reeders ST. Complete primary structure of the human a3(IV) collagen chain. Coexpression of the a3(IV) and a4(IV) collagen chains in human tissues. J Biol Chem. 1994; 269:23013-23017. [PubMed: 8083201]

Martin P, Heiskari N, Zhou J, Leinonen A, Tumelius T, Hertz JM, Barker D, Gregory M, Atkin C, Styrkarsdottir U, Neumann H, Springate J, Shows T, Pettersson E, Tryggvason K. High mutation detection rate in the COL4A5 collagen gene in suspected Alport syndrome using PCR and direct DNA sequencing. J Am Soc Nephrol. 1998; 9:2291-2301. [PubMed: 9848783]

Matsuoka Y, Kubota H, Adachi E, Nagai N, Marutani T, Hosokawa N, Nagata K. Insufficient folding of type IV collagen and formation of abnormal basement membrane-like structure in embryoid bodies derived from Hsp47-null embryonic stem cells. Mol Biol Cell. 2004; 15:4467-4475. [PubMed: 15282337]

Melchiori A, Mortarini R, Carlone S, Marchisio PC, Anichini A, Noonan DM, Albini A. The a3 $\beta 1$ integrin is involved in melanoma cell migration and invasion. Exp Cell Res. 1995; 219:233-242. [PubMed: 7628538]

Miles AJ, Skubitz AP, Furcht LT, Fields GB. Promotion of cell adhesion by single-stranded and triplehelical peptide models of basement membrane collagen a1(IV)531-543. Evidence for conformationally dependent and conformationally independent type IV collagen cell adhesion sites. J Biol Chem. 1994; 269:30939-30945. [PubMed: 7983028]

Miles AJ, Knutson JR, Skubitz AP, Furcht LT, McCarthy JB, Fields GB. A peptide model of basement membrane collagen a1(IV)531-543 binds the a3 $\beta 1$ integrin. J Biol Chem. 1995; 270:2904729050. [PubMed: 7493922]

Mochizuki T, Lemmink HH, Mariyama M, Antignac C, Gubler MC, Pirson Y, Verellen-Dumoulin C, Chan B, Schröder CH, Smeets HJ, Reeders ST. Identification of mutations in the a3(IV) and a4(IV) collagen genes in autosomal recessive Alport syndrome. Nat Genet. 1994; 8:77-81. [PubMed: 7987396]

Morrison KE, Germino GG, Reeders ST. Use of the polymerase chain reaction to clone and sequence a cDNA encoding the bovine a3 chain of type IV collagen. J Biol Chem. 1991a; 266:34-39. [PubMed: 1985905]

Morrison KE, Mariyama M, Yang-Feng TL, Reeders ST. Sequence and localization of a partial cDNA encoding the human a3 chain of type IV collagen. Am J Hum Genet. 1991b; 49:545-554. [PubMed: 1882840]

Murray JC, Stingl G, Kleinman HK, Martin GR, Katz SI. Epidermal cells adhere preferentially to type IV (basement membrane) collagen. J Cell Biol. 1979; 80:197-202. [PubMed: 422650]

Myers JC, Jones TA, Pohjolainen ER, Kadri AS, Goddard AD, Sheer D, Solomon E, Pihlajaniemi T. Molecular cloning of a5(IV) collagen and assignment of the gene to the region of the $\mathrm{X}$ 
chromosome containing the Alport syndrome locus. Am J Hum Genet. 1990; 46:1024-1033. [PubMed: 2339699]

Myllyharju J, Kivirikko KI. Collagens, modifying enzymes and their mutations in humans, flies and worms. Trends Genet. 2004; 20:33-43. [PubMed: 14698617]

Nagai N, Hosokawa M, Itohara S, Adachi E, Matsushita T, Hosokawa N, Nagata K. Embryonic lethality of molecular chaperone hsp47 knockout mice is associated with defects in collagen biosynthesis. J Cell Biol. 2000; 150:1499-1506. [PubMed: 10995453]

Nayak BR, Spiro RG. Localization and structure of the asparagine-linked oligosaccharides of type IV collagen from glomerular basement membrane and lens capsule. J Biol Chem. 1991; 266:1397813987. [PubMed: 1856226]

Netzer KO, Merkel F, Weber M. Goodpasture syndrome and end-stage renal failure to transplant or not to transplant? Nephrol Dial Transplant. 1998a; 13:1346-1348. editorial. [PubMed: 9641155]

Netzer KO, Suzuki K, Itoh Y, Hudson BG, Khalifah RG. Comparative analysis of the non-collagenous $\mathrm{NC} 1$ domain of type IV collagen: Identification of structural features important for assembly, function and pathogenesis. Protein Sci. 1998b; 7:1340-1351. [PubMed: 9655338]

Netzer KO, Leinonen A, Boutaud A, Borza DB, Todd P, Gunwar S, Langeveld JP, Hudson BG. The Goodpasture autoantigen. Mapping the major conformational epitope(s) of a3(IV) collagen to residues 17-31 and 127-141 of the NC1 domain. J Biol Chem. 1999; 274:11267-11274. [PubMed: 10196215]

Oohashi T, Sugimoto M, Mattei MG, Ninomiya Y. Identification of a new collagen IV chain, a6(IV), by cDNA isolation and assignment of the gene to chromosome $\mathrm{Xq} 22$, which is the same locus for COL4A5. J Biol Chem. 1994; 269:7520-7526. [PubMed: 8125972]

Pasco S, Monboisse JC, Kieffer N. The a3(IV)185-206 peptide from noncollagenous domain 1 of type IV collagen interacts with a novel binding site on the $\beta 3$ subunit of integrin $\alpha \mathrm{V} \beta 3$ and stimulates focal adhesion kinase and phosphatidylinositol 3-kinase phosphorylation. J Biol Chem. 2000; 275:32999-33007. [PubMed: 10934203]

Pasternak JF, Mantovani JF, Volpe JJ. Porencephaly from periventricular intracerebral hemorrhage in a premature infant. Am J Dis Child. 1980; 134:673-675. [PubMed: 7395828]

Paulsson M. Basement membrane proteins: Structure, assembly, and cellular interactions. Crit Rev Biochem Mol Biol. 1992; 27:93-127. [PubMed: 1309319]

Pedchenko V, Zent R, Hudson BG. $\alpha_{\mathrm{v}} \beta_{3}$ and $\alpha_{\mathrm{v}} \beta_{5}$ integrins bind both the proximal RGD site and nonRGD motifs within noncollagenous ( $\mathrm{NC} 1$ ) domain of the a 3 chain of type IV collagen: Implication for the mechanism of endothelial cell adhesion. J Biol Chem. 2004; 279:2772-2780. [PubMed: 14610079]

Perris R, Syfrig J, Paulsson M, Bronner-Fraser M. Molecular mechanisms of neural crest cell attachment and migration on types I and IV collagen. J Cell Sci. 1993; 106(Part 4):1357-1368. [PubMed: 8126113]

Petitclerc E, Boutaud A, Prestayko A, Xu J, Sado Y, Ninomiya Y, Sarras MP Jr, Hudson BG, Brooks PC. New functions for non-collagenous domains of human collagen type IV. Novel integrin ligands inhibiting angiogenesis and tumor growth in vivo. J Biol Chem. 2000; 275:8051-8061. [PubMed: 10713126]

Phelps RG, Rees AJ. The HLA complex in Goodpasture's disease: A model for analyzing susceptibility to autoimmunity. Kidney Int. 1999; 56:1638-1653. [PubMed: 10571772]

Pihlajaniemi T, Pohjolainen ER, Myers JC. Complete primary structure of the triple-helical region and the carboxyl-terminal domain of a new type IV collagen chain, a5(IV). J Biol Chem. 1990; 265:13758-13766. [PubMed: 2380186]

Pochec E, Litynska A, Amoresano A, Casbarra A. Glycosylation profile of integrin a 31 changes with melanoma progression. Biochim Biophys Acta. 2003; 1643:113-123. [PubMed: 14654234]

Porter JC, Hogg N. Integrins take partners: Cross-talk between integrins and other membrane receptors. Trends Cell Biol. 1998; 8:390-396. [PubMed: 9789327]

Prockop DJ, Kivirikko KI. Collagens: Molecular biology, diseases, and potentials for therapy. Annu Rev Biochem. 1995; 64:403-434. [PubMed: 7574488]

Quinones S, Bernal D, Garcia-Sogo M, Elena SF, Saus J. Exon/intron structure of the human a3(IV) gene encompassing the Good-pasture antigen (a3(IV)NC1). Identification of a potentially 
antigenic region at the triple helix/NC1 domain junction. J Biol Chem. 1992; 267:19780-19784. [PubMed: 1400291]

Remuzzi G, Bertani T. Pathophysiology of progressive nephropathies. N Engl J Med. 1998; 339:14481456. [PubMed: 9811921]

Renner C, Sacca B, Moroder L. Synthetic heterotrimeric collagen peptides as mimics of cell adhesion sites of the basement membrane. Biopolymers. 2004; 76:34-47. [PubMed: 14997473]

Risteli J, Bachinger HP, Engel J, Furthmayr H, Timpl R. 7-S collagen: Characterization of an unusual basement membrane structure. Eur J Biochem. 1980; 108:239-250. [PubMed: 6250829]

Roth JM, Akalu A, Zelmanovich A, Policarpio D, Ng B, MacDonald S, Formenti S, Liebes L, Brooks PC. Recombinant a2(IV)NC1 domain inhibits tumor cell-extracellular matrix interactions, induces cellular senescence, and inhibits tumor growth in vivo. Am J Pathol. 2005; 166:901-911. [PubMed: 15743801]

Rubin K, Hook M, Obrink B, Timpl R. Substrate adhesion of rat hepatocytes: Mechanism of attachment to collagen substrates. Cell. 1981; 24:463-470. [PubMed: 7237556]

Ruoslahti E. RGD and other recognition sequences for integrins. Annu Rev Cell Dev Biol. 1996; 12:697-715. [PubMed: 8970741]

Sado Y, Boutaud A, Kagawa M, Naito I, Ninomiya Y, Hudson BG. Induction of anti-GBM nephritis in rats by recombinant a3(IV)NC1 and a4(IV)NC1 of type IV collagen. Kidney Int. 1998; 53:664671. [PubMed: 9507212]

Salama AD, Chaudhry AN, Ryan JJ, Eren E, Levy JB, Pusey CD, Lightstone L, Lechler RI. In Goodpasture's disease, CD4(+) T cells escape thymic deletion and are reactive with the autoantigen a3(IV)NC1. J Am Soc Nephrol. 2001; 12:1908-1915. [PubMed: 11518784]

Santoro SA. Identification of a 160,000 dalton platelet membrane protein that mediates the initial divalent cation-dependent adhesion of platelets to collagen. Cell. 1986; 46:913-920. [PubMed: 3757029]

Sarras, M.; Hudson, B. Use of isolated domains of type IV collagen to modify cell and tissue interactions. U.S. Pat. 5, 691,182. 1997.

Saus J, Wieslander J, Langeveld JP, Quinones S, Hudson BG. Identification of the Goodpasture antigen as the a3(IV) chain of collagen IV. J Biol Chem. 1988; 263:13374-13380. [PubMed: 3417661]

Schor SL, Court J. Different mechanisms in the attachment of cells to native and denatured collagen. J Cell Sci. 1979; 38:267-281. [PubMed: 521466]

Senior RM, Hinek A, Griffin GL, Pipoly DJ, Crouch EC, Mecham RP. Neutrophils show chemotaxis to type IV collagen and its 7S domain and contain a $67 \mathrm{kD}$ type IV collagen binding protein with lectin properties. Am J Respir Cell Mol Biol. 1989; 1:479-487. [PubMed: 2561590]

Setty S, Kim Y, Fields GB, Clegg DO, Wayner EA, Tsilibary EC. Interactions of type IV collagen and its domains with human mesangial cells. J Biol Chem. 1998; 273:12244-12249. [PubMed: 9575174]

Shahan TA, Ziaie Z, Pasco S, Fawzi A, Bellon G, Monboisse JC, Kefalides NA. Identification of CD47/integrin-associated protein and $\alpha(v) \beta 3$ as two receptors for the a3(IV) chain of type IV collagen on tumor cells. Cancer Res. 1999; 59:4584-4590. [PubMed: 10493512]

Shrivastava A, Radziejewski C, Campbell E, Kovac L, McGlynn M, Ryan TE, Davis S, Goldfarb MP, Glass DJ, Lemke G, Yancopoulos GD. An orphan receptor tyrosine kinase family whose members serve as nonintegrin collagen receptors. Mol Cell. 1997; 1:25-34. [PubMed: 9659900]

Siebold B, Deutzmann R, Kuhn K. The arrangement of intra-and intermolecular disulfide bonds in the carboxyterminal, non-collagenous aggregation and cross-linking domain of basement-membrane type IV collagen. Eur J Biochem. 1988; 176:617-624. [PubMed: 2844531]

Sixma JJ, van Zanten GH, Huizinga EG, van der Plas RM, Verkley M, Wu YP, Gros P, de Groot PG. Platelet adhesion to collagen: An update. Thromb Haemost. 1997; 78:434-438. [PubMed: 9198192]

Smit LM, Barth PG, Valk J, Njiokiktjien C. Familial porencephalic white matter disease in two generations. Brain Dev. 1984; 6:54-58. [PubMed: 6428250]

Spear GS. Editorial: Alport's syndrome: A consideration of pathogenesis. Clin Nephrol. 1973; 1:336337. [PubMed: 4786573] 
Spear GS, Slusser RJ. Alport's syndrome. Emphasizing electron microscopic studies of the glomerulus. Am J Pathol. 1972; 69:213-224. [PubMed: 4343992]

Staatz WD, Walsh JJ, Pexton T, Santoro SA. The a $2 \beta 1$ integrin cell surface collagen receptor binds to the a1 (I)-CB3 peptide of collagen. J Biol Chem. 1990; 265:4778-4781. [PubMed: 2156854]

Stevenson A, Yaqoob M, Mason H, Pai P, Bell GM. Biochemical markers of basement membrane disturbances and occupational exposure to hydrocarbons and mixed solvents. QJM. 1995; 88:2328. [PubMed: 7534597]

Sudhakar A, Sugimoto H, Yang C, Lively J, Zeisberg M, Kalluri R. Human tumstatin and human endostatin exhibit distinct antiangiogenic activities mediated by av $\beta 3$ and $\alpha 5 \beta 1$ integrins. Proc Natl Acad Sci USA. 2003; 100:4766-4771. [PubMed: 12682293]

Sugimoto M, Oohashi T, Ninomiya Y. The genes COL4A5 and COL4A6, coding for basement membrane collagen chains a5(IV) and a6(IV), are located head-to-head in close proximity on human chromosome Xq22 and COL4A6 is transcribed from two alternative promoters. Proc Natl Acad Sci USA. 1994; 91:11679-11683. [PubMed: 7972123]

Sundaramoorthy M, Meiyappan M, Todd P, Hudson BG. Crystal structure of NC1 domains: Structural basis for type IV collagen assembly in basement membranes. J Biol Chem. 2002; 277:3114231153. [PubMed: 11970952]

Than ME, Henrich S, Huber R, Ries A, Mann K, Kuhn K, Timpl R, Bourenkov GP, Bartunik HD, Bode W. The 1.9- $\AA$ crystal structure of the noncollagenous (NC1) domain of human placenta collagen IV shows stabilization via a novel type of covalent Met-Lys cross-link. Proc Natl Acad Sci USA. 2002; 99:6607-6612. [PubMed: 12011424]

Tiger CF, Fougerousse F, Grundstrom G, Velling T, Gullberg D. a11ß1 Integrin is a receptor for interstitial collagens involved in cell migration and collagen reorganization on mesenchymal non-muscle cells. Dev Biol. 2001; 237:116-129. [PubMed: 11518510]

Timoshanko JR, Kitching AR, Holdsworth SR, Tipping PG. Interleukin-12 from intrinsic cells is an effector of renal injury in crescentic glomerulonephritis. J Am Soc Nephrol. 2001; 12:464-471. [PubMed: 11181794]

Timpl R, Risteli J, Bachinger HP. Identification of a new basement membrane collagen by the aid of a large fragment resistant to bacterial collagenase. FEBS Lett. 1979; 101:265-268. [PubMed: 87347]

Timpl R, Wiedemann H, van Delden V, Furthmayr H, Kuhn K. A network model for the organization of type IV collagen molecules in basement membranes. Eur J Biochem. 1981; 120:203-211. [PubMed: 6274634]

Tsilibary EC, Reger LA, Vogel AM, Koliakos GG, Anderson SS, Charonis AS, Alegre JN, Furcht LT. Identification of a multifunctional, cell-binding peptide sequence from the a1(NC1) of type IV collagen. J Cell Biol. 1990; 111:1583-1591. [PubMed: 2211826]

Tuckwell DS, Ayad S, Grant ME, Takigawa M, Humphries MJ. Conformation dependence of integrintype II collagen binding. Inability of collagen peptides to support a $2 \beta 1$ binding, and mediation of adhesion to denatured collagen by a novel a 5 1-fibronectin bridge. J Cell Sci. 1994; 107(Part 4):993-1005. [PubMed: 7520045]

Tulla M, Pentikainen OT, Viitasalo T, Kapyla J, Impola U, Nykvist P, Nissinen L, Johnson MS, Heino J. Selective binding of collagen subtypes by integrin $\{a\} 1$ I, $\{a\} 2$ I and $\{a\} 10$ I domains. J Biol Chem. 2001a; 25:25.

Tulla M, Pentikainen OT, Viitasalo T, Kapyla J, Impola U, Nykvist P, Nissinen L, Johnson MS, Heino J. Selective binding of collagen subtypes by integrin a1I, a2I, and a10I domains. J Biol Chem. 2001b; 276:48206-48212. [PubMed: 11572855]

Turner N, Mason PJ, Brown R, Fox M, Povey S, Rees A, Pusey CD. Molecular cloning of the human Goodpasture antigen demonstrates it to be the a3 chain of type IV collagen. J Clin Invest. 1992; 89:592-601. [PubMed: 1737849]

van der Knaap MS, Smit LM, Barkhof F, Pijnenburg YA, Zweegman S, Niessen HW, Imhof S, Heutink P. Neonatal porencephaly and adult stroke related to mutations in collagen IVA1. Ann Neurol. 2006; 59:504-511. [PubMed: 16374828]

Vanacore RM, Shanmugasundararaj S, Friedman DB, Bondar O, Hudson BG, Sundaramoorthy M. The a1a2-network of collagen IV: Reinforced stabilization of the noncollagenous domain-1 by 
noncovalent forces and the absence of Met-Lys crosslinks. J Biol Chem. 2004; 279:4472344730. [PubMed: 15299013]

Vanacore RM, Friedman DB, Ham AJ, Sundaramoorthy M, Hudson BG. Identification of $S$ hydroxylysyl-methionine as the covalent cross-link of the noncollagenous (NC1) hexamer of the a 1a1a2 collagen IV network: A role for the posttranslational modification of lysine 211 to hydroxylysine 211 in hexamer assembly. J Biol Chem. 2005; 280:29300-29310. [PubMed: 15951440]

Vandenberg P, Kern A, Ries A, Luckenbill-Edds L, Mann K, Kuhn K. Characterization of a type IV collagen major cell binding site with affinity to the $\alpha 1 \beta 1$ and the $\alpha 2 \beta 1$ integrins. J Cell Biol. 1991; 113:1475-1483. [PubMed: 1646206]

Veit G, Kobbe B, Keene DR, Paulsson M, Koch M, Wagener R. Collagen XXVIII, a novel von Willebrand factor A domain-containing protein with many imperfections in the collagenous domain. J Biol Chem. 2006; 281:3494-3504. [PubMed: 16330543]

Vogel W, Gish GD, Alves F, Pawson T. The discoidin domain receptor tyrosine kinases are activated by collagen. Mol Cell. 1997; 1:13-23. [PubMed: 9659899]

Vogel W, Brakebusch C, Fassler R, Alves F, Ruggiero F, Pawson T. Discoidin domain receptor 1 is activated independently of $\beta(1)$ integrin. J Biol Chem. 2000; 275:5779-5784. [PubMed: 10681566]

Wayner EA, Carter WG. Identification of multiple cell adhesion receptors for collagen and fibronectin in human fibrosarcoma cells possessing unique a and common $\beta$-subunits. J Cell Biol. 1987; 105:1873-1884. [PubMed: 2822727]

Weber S, Engel J, Wiedemann H, Glanville RW, Timpl R. Subunit structure and assembly of the globular domain of basement-membrane collagen type IV. Eur J Biochem. 1984; 139:401-410. [PubMed: 6698021]

Weitzman JB, Pasqualini R, Takada Y, Hemler ME. The function and distinctive regulation of the integrin VLA-3 in cell adhesion, spreading, and homotypic cell aggregation. J Biol Chem. 1993; 268:8651-8657. [PubMed: 8473308]

Wieslander J, Barr JF, Butkowski RJ, Edwards SJ, Bygren P, Heinegard D, Hudson BG. Goodpasture antigen of the glomerular basement membrane: Localization to noncollagenous regions of type IV collagen. Proc Natl Acad Sci USA. 1984; 81:3838-3842. [PubMed: 6328527]

Wieslander J, Langeveld J, Butkowski R, Jodlowski M, Noelken M, Hudson BG. Physical and immunochemical studies of the globular domain of type IV collagen. Cryptic properties of the Good-pasture antigen. J Biol Chem. 1985; 260:8564-8570. [PubMed: 2409091]

Wilke MS, Furcht LT. Human keratinocytes adhere to a unique heparin-binding peptide sequence within the triple helical region of type IV collagen. J Invest Dermatol. 1990; 95:264-270. [PubMed: 2384687]

Wong D, Phelps RG, Turner AN. The Goodpasture antigen is expressed in the human thymus. Kidney Int. 2001; 60:1777-1783. [PubMed: 11703595]

Wu J, Hicks J, Ou C, Singleton D, Borillo J, Lou YH. Glomerulonephritis induced by recombinant collagen IV a3 chain noncollagen domain 1 is not associated with glomerular basement membrane antibody: A potential T cell-mediated mechanism. J Immunol. 2001; 167:2388-2395. [PubMed: 11490029]

Wu J, Hicks J, Borillo J, Glass WF II, Lou YH. CD4(+) T cells specific to a glomerular basement membrane antigen mediate glomerulonephritis. J Clin Invest. 2002; 109:517-524. [PubMed: 11854324]

Xu J, Rodriguez D, Petitclerc E, Kim JJ, Hangai M, Yuen SM, Davis GE, Brooks PC. Proteolytic exposure of a cryptic site within collagen type IV is required for angiogenesis and tumor growth in vivo. J Cell Biol. 2001; 154:1069-1080. [PubMed: 11535623]

Yurchenco PD, Furthmayr H. Self-assembly of basement membrane collagen. Biochemistry. 1984; 23:1839-1850. [PubMed: 6722126]

Yurchenco PD, Ruben GC. Basement membrane structure in situ: Evidence for lateral associations in the type IV collagen network. J Cell Biol. 1987; 105(6, Part 1):2559-2568. [PubMed: 3693393]

Zhang X, Hudson BG, Sarras MP Jr. Hydra cell aggregate development is blocked by selective fragments of fibronectin and type IV collagen. Dev Biol. 1994; 164:10-23. [PubMed: 8026615] 
Zhang WM, Kapyla J, Puranen JS, Knight CG, Tiger CF, Pentikainen OT, Johnson MS, Farndale RW, Heino J, Gullberg D. a11 $\beta 1$ Integrin recognizes the GFOGER sequence in interstitial collagens. J Biol Chem. 2003; 278:7270-7277. [PubMed: 12496264]

Zhou J, Reeders ST. The a-chains of type IV collagen. Contrib Nephrol. 1996; 117:80-104. [PubMed: 8801049]

Zhou J, Mochizuki T, Smeets H, Antignac C, Laurila P, de Paepe A, Tryggvason K, Reeders ST. Deletion of the paired a5(IV) and a6(IV) collagen genes in inherited smooth muscle tumors. Science. 1993; 261:1167-1169. [PubMed: 8356449]

Zhou J, Ding M, Zhao Z, Reeders ST. Complete primary structure of the sixth chain of human basement membrane collagen, a6(IV). Isolation of the cDNAs for a6(IV) and comparison with five other type IV collagen chains. J Biol Chem. 1994; 269:13193-13199. [PubMed: 8175748] 


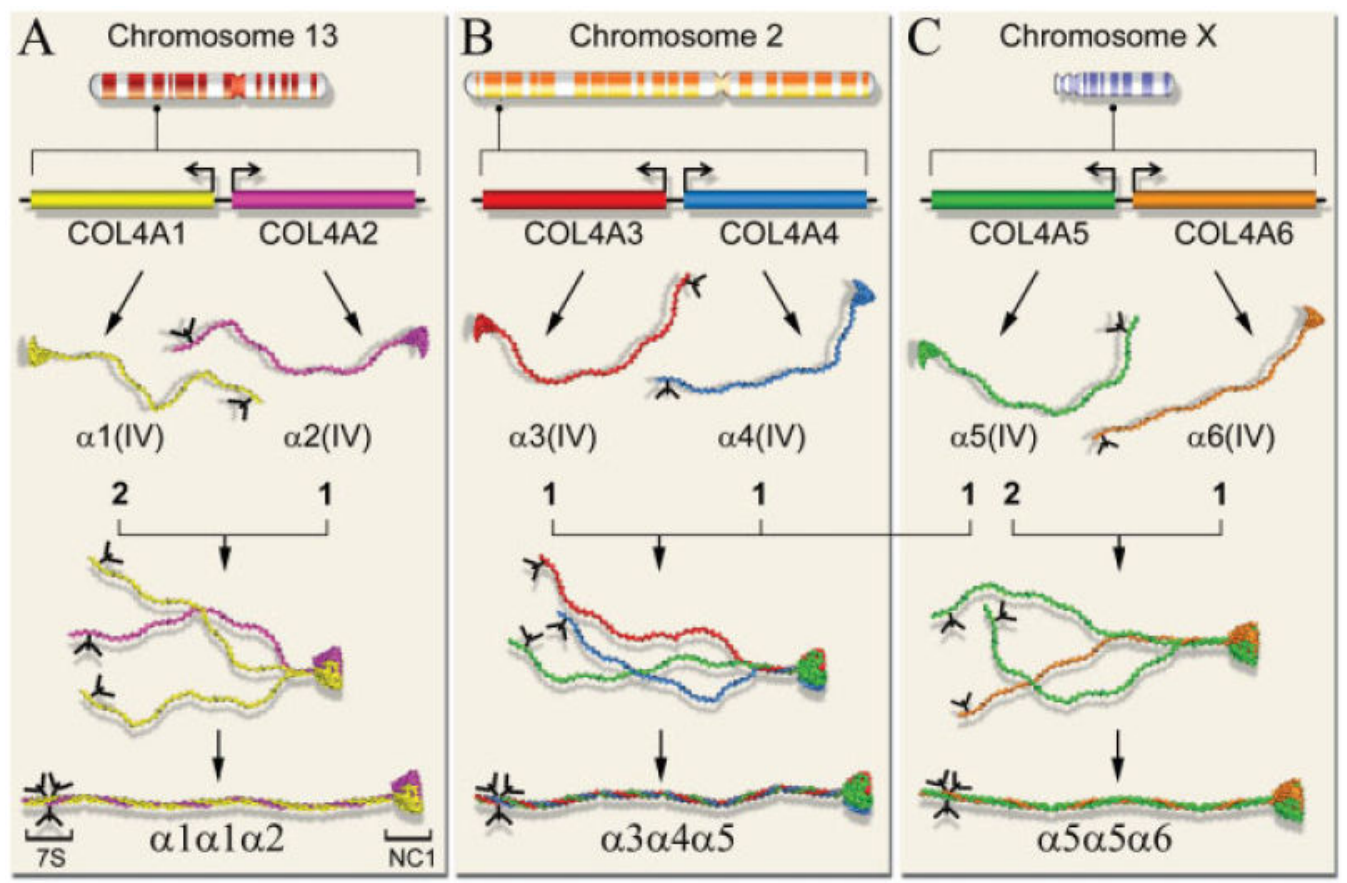

Fig. 1.

Schematic view of gene localization, organization, gene product, and assembly of six different isoforms of human collagen IV chains. The genes, COLAA1/COL4A2 on chromosome 13 (A), COL4A3/COL4A4 on chromosome 2 (B), and COL4A5/COL4A6 on chromosome $\mathrm{X}(\mathbf{C})$, are organized in pair sitting head-to-head and separated by a short promoter region that both genes share. The paired genes are transcribed in a bidirectional fashion and translated into individual a-chains. Each chain starts with an N-terminal $7 \mathrm{~S}$ domain having an $N$-linked oligosaccharide (Y-shaped and black), a long collagenous domain, and a C-terminal globular noncollagenous domain (NC1). Assembly of each heterotrimer with characteristic stoichiometry of chains initiates by chain-specific recognition of $\mathrm{NC1}$ domains, formation of NC1-trimers followed by supercoiling of the triple-helical collagenous domains which proceeds toward the $\mathrm{N}$-terminal $7 \mathrm{~S}$ domains. Out of 56 potential heterotrimers, only three specific combinations: a1a1a2, a $3 a 4 a 5$, and a 5 a 5 a6, have been found in vivo. 
A

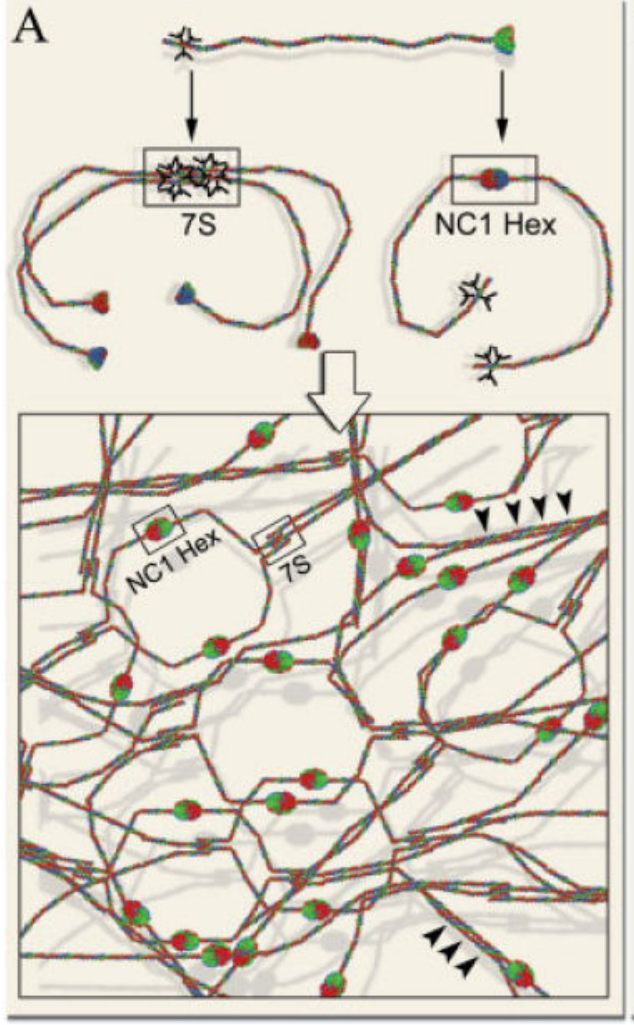

B

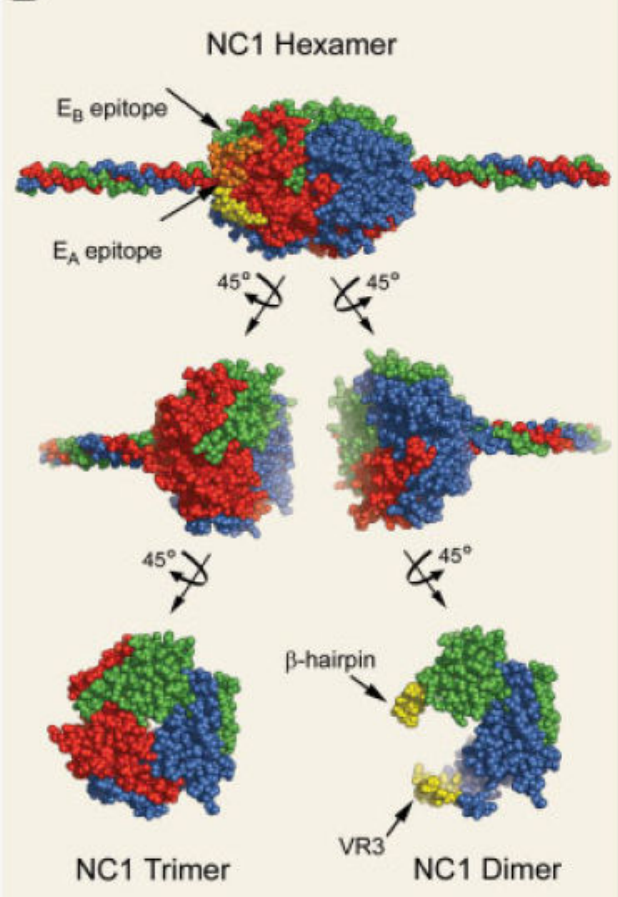

Fig. 2.

Generic network formation and structural features of the NC1 domain. A heterotrimeric collagen IV molecule (A) can interact through its $\mathrm{N}$-terminal 7S domains to form a tetramer (left) or through its $\mathrm{NC1}$ domains to form a dimer (right). Through complex interactions, these molecules can further interact to form higher order of supramolecular organization and three-dimensional networks. The networks are further enforced by supramolecular twisting and lateral associations of collagenous domains (arrow heads). Domain organization and configuration of the $\mathrm{NC} 1$ domains in hexamer and trimer $(\mathbf{B})$. The $\mathrm{NC} 1$ hexamer is formed by end-to-end interaction of two NC1 trimers. Relative location of two immunologically reactive epitopes, EA (yellow) and $\mathrm{EB}$ (orange) on the alpha3(IV) NC1 domain are shown. Each $\mathrm{NC} 1$ trimer is stabilized by a three-dimensional domain swapping mechanism through tight and selective interactions between two sites comprising a beta-hairpin motif and its docking site with a variable region (VR3). 


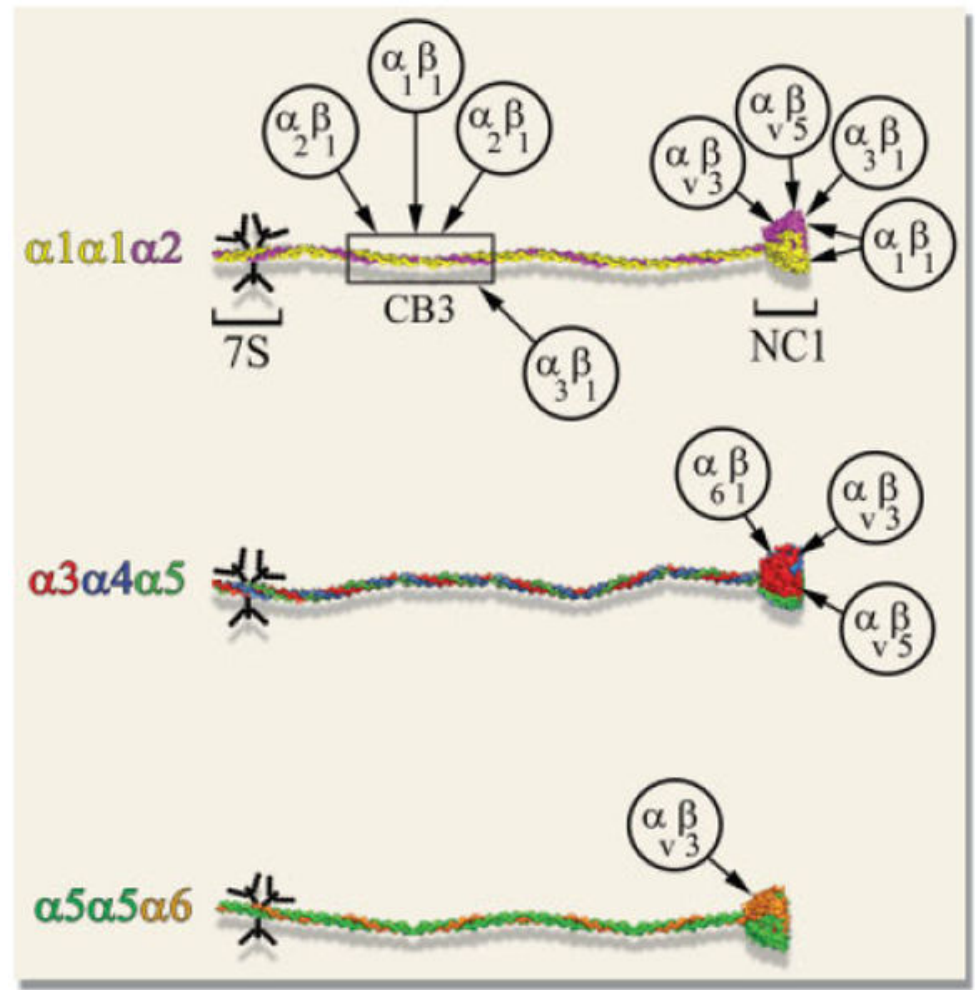

Fig. 3.

Location of integrin-binding sites within three different collagen IV heterotrimers. Binding sites within the triple-helical cyanogen bromide-derived fragment (CB3) and specific NC1 domains are indicated. 


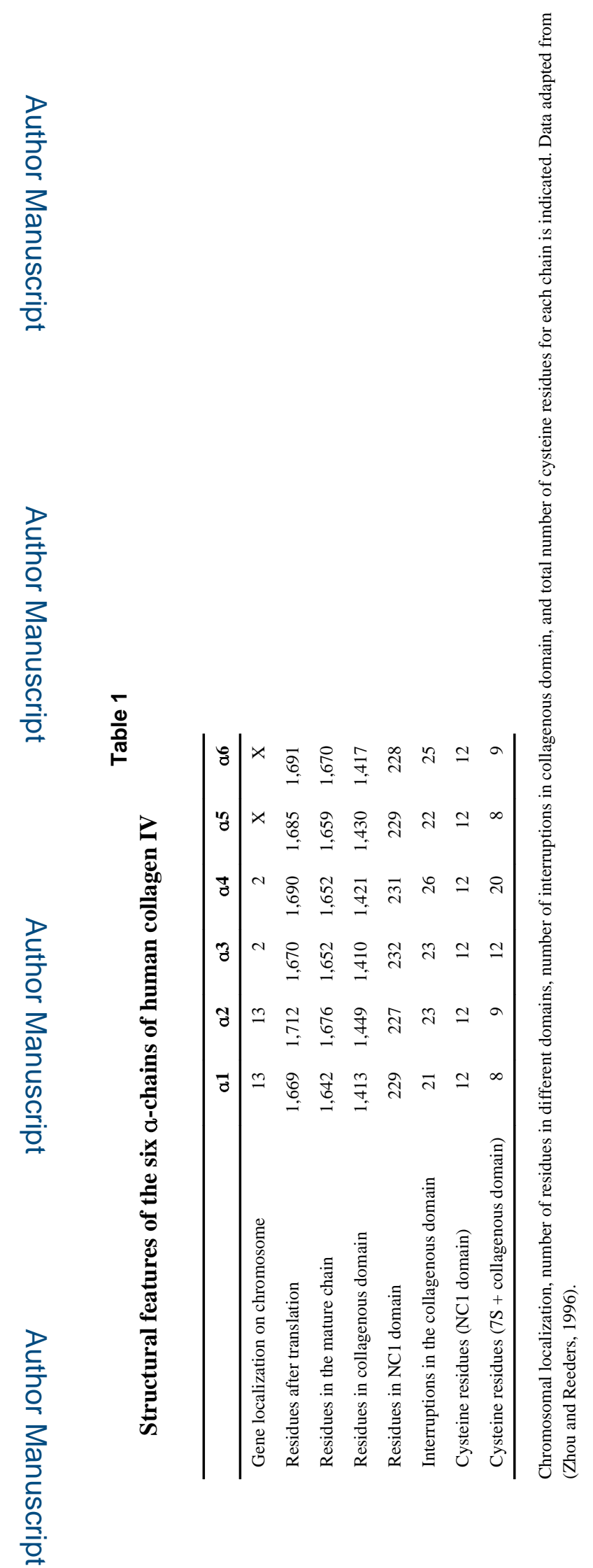

Microsc Res Tech. Author manuscript; available in PMC 2016 March 11. 